\title{
Glaciers and rivers: Pleistocene uncoupling in a Mediterranean mountain karst
}

\author{
K.R. Adamson ${ }^{\mathrm{a}, \mathrm{b}, *}$, J.C. Woodward ${ }^{\mathrm{c}}$, P.D. Hughes ${ }^{\mathrm{c}}$ \\ a School of Geography, Queen Mary, University of London, Mile End Road, London E1 4NS, UK \\ ${ }^{\mathrm{b}}$ Geography, School of Science and the Environment, Manchester Metropolitan University, Manchester M1 5GD, UK \\ ${ }^{\mathrm{c}}$ Quaternary Environments and Geoarchaeology Research Group, Geography, School of, Environment, Education and Development, \\ The University of Manchester, Manchester M13 9PL, UK
}

\section{A R T I C L E I N F O}

\section{Article history:}

Received 28 October 2013

Received in revised form

9 April 2014

Accepted 16 April 2014

Available online

\section{Keywords:}

Pleistocene

Mediterranean

Karst

Coupling

Glacial

Fluvial

Outwash

\begin{abstract}
A B S T R A C T
Large-scale coupling between headwater catchments and downstream depocentres is a critical influence on long-term fluvial system behaviour and on the creation of the fluvial sedimentary record. However, it is often difficult to examine this control over multiple Quaternary glacial cycles and it has not been fully explored in karst basins. By investigating the Pleistocene glacial and fluvial records on and around Mount Orjen $(1894 \mathrm{~m})$ in Montenegro, we show how the changing connectivity between glaciated mountain headwater source zones and downstream alluvial basins is a key feature of long-term karst system behaviour - especially in relation to the creation and preservation of the surface sedimentary record. Middle and Late Pleistocene glacial deposits are well preserved on Mount Orjen. Uranium-series dating of 27 carbonate cements in fluvial sediments shows that many alluvial depocentres were completely filled with coarse glacial outwash before $350 \mathrm{ka}$ during the largest recorded glaciation. This major glaciation is correlated with the Skamnellian Stage in Greece and Marine Isotope Stage 12 (MIS 12, c 480 $-420 \mathrm{ka}$ ). This was a period of profound landscape change in many glaciated catchments on the Balkan Peninsula. Later glaciations were much less extensive and sediment supply to fluvial systems was much diminished. The extreme base level falls of the Late Miocene produced the world's deepest karst networks around the Mediterranean. After MIS 12, the subterranean karst of Mount Orjen formed the dominant pathway for meltwater and sediment transfer so that the depositional basins below $1000 \mathrm{~m}$ became disconnected (uncoupled) from the glaciated headwaters. There is little evidence of post-MIS 12 aggradation or incision in these basins. This absence of later Pleistocene and Holocene fluvial activity means these basins contain some of the thickest and best-preserved outwash deposits in the Mediterranean.
\end{abstract}

(c) 2014 Elsevier Ltd. All rights reserved.

\section{Introduction}

Pleistocene glaciation of the Mediterranean mountains was first recognised over a century ago (Cvijić, 1898, 1900), but it is only in the last few decades that systematic mapping and radiometric dating have begun to reveal the complexity of this record (Woodward et al., 2004; Hughes and Woodward, 2009). It is now well established that ice caps and glaciers varied greatly in size between the cold stages of the Middle and Late Pleistocene (Hughes et al., 2006a, 2010; Lewis et al., 2009; Calvet et al., 2011). Glacial

\footnotetext{
* Corresponding author. School of Geography, Queen Mary, University of London, Mile End Road, London, E1 4NS, UK. Tel.: +44(0)20 87726170.

E-mail addresses: k.adamson@qmul.ac.uk, k.adamson@mmu.ac.uk(K.R. Adamson).
}

sediments and landforms are especially well preserved in the limestone uplands of southern Europe. In the Pindus Mountains of Greece and the Dinaric Alps of Montenegro, we have evidence for at least four phases of glaciation: each has been dated by uraniumseries (U-series) methods ( $n=59$ dates) (Woodward et al., 2004: Hughes et al., 2006a,b, 2010, 2011). These glaciations were successively smaller and occurred during three cold stages: the Skamnellian, Vlasian and Tymphian Stages. Hughes et al. (2005, 2006a) used a continuous parastratotype at Lake Ioannina in Greece to correlate these cold stages with Marine Isotope Stages (MIS) $12 ; 6$; 5d-2, respectively. The final episode of Pleistocene glaciation took place at the end of the Tymphian Stage and is correlated with the Younger Dryas (Hughes et al., 2006b). This was marked by a climatic deterioration across Europe (12.9-11.7 cal ka BP; defined as a chronozone spanning the interval 11$10{ }^{14} \mathrm{C}$ ka BP by Mangerud and Donner, 1974). 
A key objective is to establish the impact of past glacial activity on Pleistocene river basin processes across the Mediterranean, from the mountains to the coastal zone. The Pleistocene alluvial record in the glaciated catchments of the Mediterranean can form an indirect record of headwater glacial history (Lewin et al., 1991; Woodward et al., 2008). We can investigate this record to explore changes in the long-term transfer, or coupling (Harvey, 2002), between the sources of glacial outwash and river depositional settings downstream. Previous attempts to explore these interactions, over several glacial-interglacial cycles, have been hampered by limited dating control for the glacial record (Conchon, 1978; Woodward et al., 1995; Smith et al., 1997) and by limited preservation of Middle Pleistocene fluvial deposits in many river basins (Macklin et al., 2002; Macklin and Woodward, 2009, Table 1).

There is also a need to consider the role of the karst system as both conduit and store for meltwater and glaciofluvial sediment (Bočić et al., 2012). This is particularly important given that limestone karst dominates many glaciated catchments across the northern Mediterranean and in other parts of the world (e.g. Kiernan et al., 2001; Burger, 2004; Ford and Williams, 2007; Lewin and Woodward, 2009; Colhoun et al., 2010). Our understanding of glacial and fluvial system interactions within karst landscapes is currently limited (Colhoun et al., 2010). The Mediterranean is a distinctive setting in which to explore the role of karst systems on glacial-fluvial dynamics due to the extreme base level falls ( $>1500 \mathrm{~m}$ ) associated with the Messinian Salinity Crisis (MSC). The MSC was a period of near complete desiccation of the Mediterranean Sea during the Late Miocene (c 5.96-5.33 Ma), when dramatic falls in regional base level produced some of the world's deepest karst drainage networks (Mocochain et al., 2006). A key aim is to examine long-term patterns of fluvial sedimentation as the boundary conditions for river basin processes (e.g. the extent of glaciation and volume of outwash) shifted over several glacialinterglacial cycles. To this end we have investigated the Pleistocene sedimentary records in a suite of alluvial depositional settings in the karst landscapes flanking Mount Orjen on the Adriatic coast of Montenegro (Fig. 1).

\section{Mount Orjen Karst and the glacial record}

Orjen $(1894 \mathrm{~m})$ comprises several peaks on a large upland limestone karst plateau ( $>1000 \mathrm{~m}$ a.s.l.) bounded by steep slopes and a radial network of poljes, valleys, and fans. The plateau has well-developed karst topography with extensive pavements, dolines, and sinkholes, which are characteristic of the classic karst landscapes within glaciated basins across Montenegro (Hughes et al., 2011; Stepišnik and Žebre, 2011) and elsewhere in the Mediterranean uplands (Gams, 1969, 1978, 2005; Lewin and Woodward, 2009; Telbisz, 2010a, b; Woodward and Hughes, 2011; Bočić et al., 2012). The area contains a well-developed network of caverns and deep subterranean passages (Stepišnik et al., 2009). Runoff from Orjen is dominated by subterranean karst flows, many of which discharge via submarine springs in the Bay of Kotor and the Adriatic Sea (Bortoluzzi et al., 2009). Some have been mapped by speleologists (Tisserant, 1974; Groupe Spéléologique Muséum National d'Histoire Naturelle, Paris, 2003), but little scientific exploration has taken place.

This part of the Balkans is one of the wettest places in Europe (Magaš, 2002; Ducić et al., 2012). Over the period 1961-1990 the meteorological station at Crkvice (937 $\mathrm{m}$ a.s.l.) recorded a precipitation average of $4593 \mathrm{~mm}$ (Ducić et al., 2012). The value is likely to be substantially higher $(>5000 \mathrm{~mm})$ in the nearby mountains, which reach $1894 \mathrm{~m}$ a.s.l. Large ice caps formed on Mount Orjen during the Middle and Late Pleistocene. There is well-preserved evidence of at least four glacial phases. These have been U-series dated ( $n=12$ ) and correlated to the Skamnellian Stage (MIS 12), Vlasian Stage (MIS 6), Tymphian Stage (MIS 5d-2), and the Younger Dryas (Hughes et al., 2010). The extent and thickness of these ice masses decreased significantly during the course of the Middle and Late Pleistocene (Fig. 1). During the Skamnellian Stage (MIS 12) a large ice cap covered the plateau and the highest peaks, and ice lobes extended into the valleys and poljes below $1000 \mathrm{~m}$. The excellent preservation of the moraines makes an older age unlikely. Large glaciers also formed during the Vlasian Stage (MIS 6), but did not extend beyond the $1000 \mathrm{~m}$ contour (Fig. 1). The glaciers of the

Table 1

Examples of dated Early to Middle Pleistocene alluvial sequences in the Mediterranean.

\begin{tabular}{|c|c|c|c|c|}
\hline Location & Author & Dating method & Age & MIS \\
\hline \multirow[t]{6}{*}{ Rio Aguas, southeast Spain } & Candy et al. (2004) & U-Series & $155 \pm 9 \mathrm{ka}$ & 6 \\
\hline & & & $207 \pm 11 \mathrm{ka}$ & 7 \\
\hline & Schulte et al. (2008) & U-Series & $148 \pm 8 \mathrm{ka}$ & 6 \\
\hline & & & $167 \pm 7 \mathrm{ka}$ & 12 \\
\hline & & & $169 \pm 9 \mathrm{ka}$ & \\
\hline & & & $>350 \mathrm{ka}$ & \\
\hline \multirow[t]{4}{*}{ Guadalope, northeast Spain } & Fuller et al. (1998) & IRSL & $157 \pm 15 \mathrm{ka}$ & 6 \\
\hline & & & $122 \pm 17 \mathrm{ka}$ & \\
\hline & & & $188 \pm 39 \mathrm{ka}$ & \\
\hline & & & $130 \pm 15 \mathrm{ka}$ & \\
\hline \multirow[t]{9}{*}{ Cinca and Gallego rivers, northeast Spain } & Peña et al. (2004a, 2004b) & OSL & $148 \pm 7 \mathrm{ka}-156 \pm 22 \mathrm{ka}$ & 6 \\
\hline & & & $176 \pm 14 \mathrm{ka}$ & \\
\hline & & & $177 \pm 22 \mathrm{ka}$ & \\
\hline & & & $180 \pm 12 \mathrm{ka}$ & \\
\hline & Lewis et al. (2009) & OSL & $134 \pm 9 \mathrm{ka}$ & 6 \\
\hline & & & $155 \pm 24 \mathrm{ka}$ & \\
\hline & & & $156 \pm 10 \mathrm{ka}$ & \\
\hline & & & $171 \pm 22 \mathrm{ka}$ & \\
\hline & & & $180 \pm 12 \mathrm{ka}$ & \\
\hline \multirow[t]{3}{*}{ Antas and Almanzora rivers, southeast Spain } & Hoffmann (1988) & ESR & $421-505 \mathrm{ka}$ & 12 \\
\hline & Wenzens (1992) & & $1.4-1.7 \mathrm{Ma}$ & $45-58$ \\
\hline & & & $2.4 \mathrm{Ma}$ & 94 \\
\hline Gediz River Basin, western Turkey & Maddy et al. (2012) & $\mathrm{K}-\mathrm{Ar}$ & $1.26-1 \mathrm{Ma}$ & $38-28$ \\
\hline River Tigris, southeast Turkey & Bridgland et al. (2007) & $\mathrm{K}-\mathrm{Ar}$ & $1.20 \pm 0.02 \mathrm{Ma} 1.31 \pm 0.06 \mathrm{Ma}$ & 36 \\
\hline \multirow[t]{3}{*}{ Wadi Zewana, northeast Libya } & Rowan et al. (2000) & U-series & $140 \pm 10 \mathrm{ka}$ & 6 \\
\hline & & & $179 \pm 14 \mathrm{ka}$ & 7 \\
\hline & & & $201 \pm 19 \mathrm{ka}$ & \\
\hline
\end{tabular}




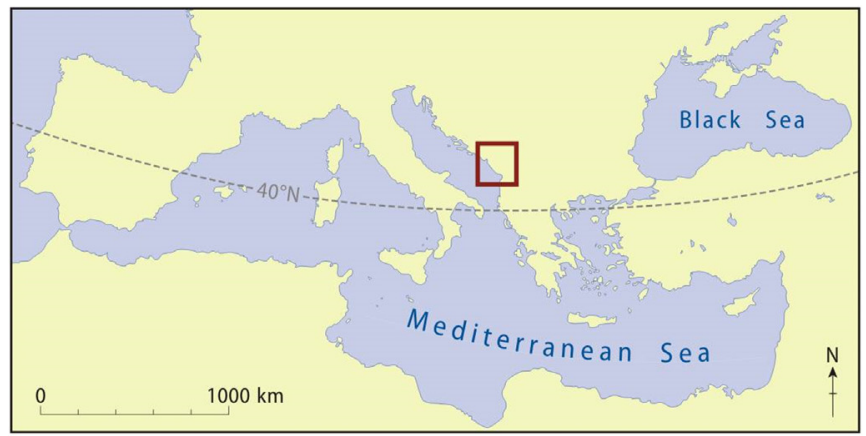

\begin{tabular}{|c|c|c|}
\hline$-\cdot-\cdot-$ & National boundary & Outwash sediment \\
\hline$\square$ & Settlement & Meltwater route \\
\hline $\boldsymbol{\Delta}$ & $\begin{array}{l}\text { Zubački kabao } \\
(1894 \mathrm{~m})\end{array}$ & Moraine crest \\
\hline & $1000 \mathrm{~m}$ contour & (MIS 12) \\
\hline$\star$ & Study site & $\begin{array}{l}\text { Ice extent } \\
\text { (MIS 6) }\end{array}$ \\
\hline$>350 \mathrm{ka}$ & U-series age & $\begin{array}{l}\text { Ice extent } \\
\text { (MIS } 5 d-2 \text { and YD) }\end{array}$ \\
\hline
\end{tabular}

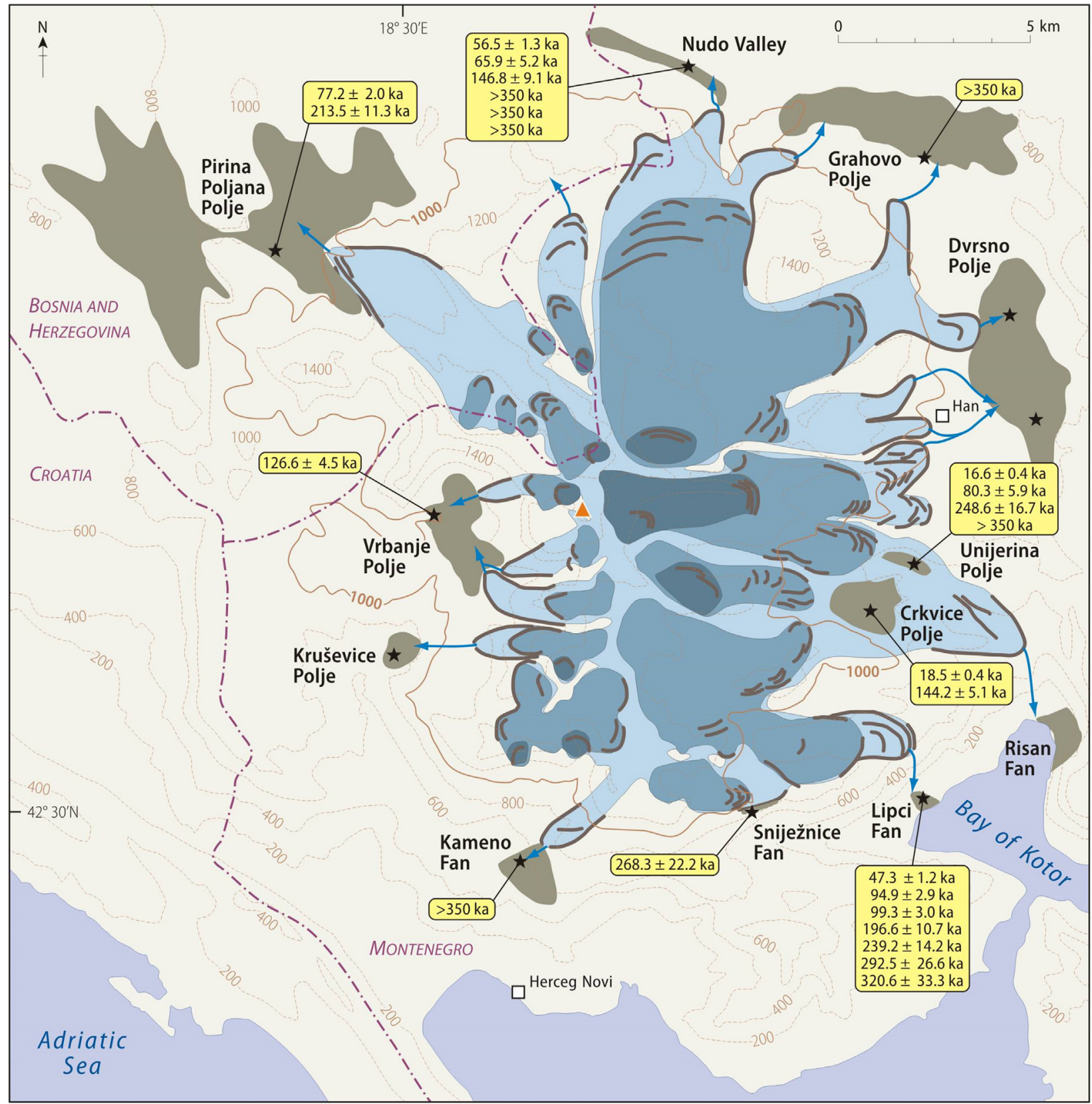

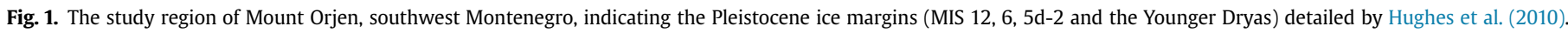
Field sites surrounding the Orjen massif are indicated. 
Table 2

Plateau ( $>1000 \mathrm{~m}=232.9 \mathrm{~km}^{2}$ ) ice cover of Mount Orjen during the Middle and Late Pleistocene.

\begin{tabular}{|c|c|c|c|c|c|}
\hline \multicolumn{6}{|c|}{ Orjen plateau ( $>1000 \mathrm{~m}$ a.s.l.) area $\left(\mathrm{km}^{2}\right)=232.9$} \\
\hline Cold Stage & Total ice extent $\left(\mathrm{km}^{2}\right)$ & Ice cover on plateau $\left(\mathrm{km}^{2}\right)$ & $\%$ plateau with ice cover & Ice thickness $(\mathrm{m})$ & Lowest elevation of ice margin ( $\mathrm{m}$ a.s.l.) \\
\hline MIS 12 & 165.0 & 136.0 & 58.4 & 450.0 & 550.0 \\
\hline MIS 6 & 85.0 & 77.4 & 33.2 & 250.0 & 700.0 \\
\hline MIS $5 d-2$ & 6.6 & 6.6 & 2.8 & 125.0 & 1200.0 \\
\hline YD & 1.0 & 1.0 & 0.4 & - & - \\
\hline
\end{tabular}

Tymphian Stage (between 110.8 and 11.7 ka; MIS 5d-2) were much smaller and restricted to the highest peaks (Hughes et al., 2010). Table 2 shows the changing boundary conditions for downstream fluvial processes during the cold stages of the Pleistocene as the Orjen uplands shifted from a glacial regime to one dominated by karst.

During the Skamnellian Stage (MIS 12) there was $136 \mathrm{~km}^{2}$ of ice on the plateau with a maximum ice thickness of $450 \mathrm{~m}$ (Table 2). During the last cold stage (MIS 5d-2 and the Younger Dryas) these values were just $6.6 \mathrm{~km}^{2}$ and $125 \mathrm{~m}$ respectively. It is likely that the warm-based thermal regime of the Orjen glaciers contributed significant volumes of basal meltwater to the sub-glacial karst network. On the basis of terrestrial morpholithostratigraphy, as well as supporting U-series ages, the glacial record of Mount Orjen can be correlated to the glacial records of northwest Greece (Woodward et al., 2004; Hughes et al., 2006a) and northwest Montenegro (Hughes et al., 2011) which also indicate a major glacial phase during the Skamnellian Stage (MIS 12). It is, of course, a partial record of past glacial events since it is possible that glaciers developed during other cold stages, such as between the Skamnellian and Vlasian Stages (MIS 10 and 8) for example, but their deposits must have been overridden by later glaciations. In the rest of this paper we refer to the marine isotope stages, noting the relationship between this globally recognised signal and the terrestrial glacial chronostratigraphy defined above in the Pindus Mountains of Greece.

\section{Field and laboratory methods}

Pleistocene fluvial sediments are well preserved on the flanks of the Orjen Massif in a range of depositional settings, both inside and outside the maximum MIS 12 ice margins. Fig. 1 shows the spatial extent of the 12 major outwash depocentres that we have investigated and their relationship to the former ice limits. Two of these sites (Crkvice and Unijerina poljes) are situated immediately downstream of the MIS 6 moraines but within the MIS 12 glaciation. Excellent exposures are present in aggregate quarries or natural sections.

\subsection{Geomorphological mapping and sedimentology}

Fluvial landforms were recorded onto 1:25,000 base maps detailed field mapping was supported by satellite and aerial photographs. Sedimentary exposures $(n=48)$ at all 12 sites were logged in detail using standard field techniques, noting key parameters such as sedimentary structures, colour, clast fabric and roundness.

\subsection{Soil profile development index}

The Harden index was used as a relative age tool and a basis for correlation between land surfaces (see Harden, 1982; Birkeland, 1999; Hughes et al., 2006a, 2010). Nine parameters were used to devise a soil profile development index (PDI) (Birkeland, 1999). Rubification, colour paling, melanisation and structure were assessed in the field and verified in the laboratory. Wet, moist and dry consistency, clay films, and $\mathrm{pH}$ were determined in the laboratory.

\subsection{Geochronology}

The coarse-grained alluvial deposits at Orjen are frequently well-cemented with secondary carbonate benches and calcite rinds, which are well-suited to Uranium-series (U-series) dating techniques. This approach has been successfully applied to the Pleistocene glacial and fluvial records of the Pindus Mountains, northwest Greece (Hamlin et al., 2000; Woodward et al., 2004, 2008; Hughes et al., 2006; Woodward and Hughes, 2011). Samples were collected in the field $(n=27)$ on the basis that: the crystals formed in-situ; there is no evidence of open system behaviour or overprinting; all calcites were densely cemented and free of detrital grains. In the laboratory, surface detritus was removed using $10 \% \mathrm{HCl}$ and deionised water. Clean crystals were selected from individual horizons using a light microscope and crushed to a fine powder. All chemical preparation and isotope analyses were undertaken at the UK Natural Environment Research Council Open University Uranium Series Facility (OUUSF) with a Nu

Table 3

The Pleistocene alluvial records around Mount Orjen.

\begin{tabular}{|c|c|c|c|c|c|c|}
\hline Site name & Location & Elevation (m a.s.l.) & Catchment area $\left(\mathrm{km}^{2}\right)$ & Polje area $\left(\mathrm{km}^{2}\right)$ & $\begin{array}{l}\text { Distance from MIS } \\
12 \text { ice margin }(\mathrm{m})\end{array}$ & Exposure thickness (m) \\
\hline Grahovo polje & $42.6492^{\circ} \mathrm{N} 18.6512^{\circ} \mathrm{E}$ & 722 & 38.5 & 8.5 & 1390 & 3 \\
\hline Dvrsno polje & $42.6130^{\circ} \mathrm{N} 18.6795^{\circ} \mathrm{E}$ & 623 & 28.5 & 8.9 & 950 & 10 \\
\hline Kruševice polje & $42.5307^{\circ} \mathrm{N} 18.4910^{\circ} \mathrm{E}$ & 632 & 8.5 & 0.7 & 2000 & 9 \\
\hline Vrbanje polje & $42.5663^{\circ} \mathrm{N} 18.4954^{\circ} \mathrm{E}$ & 982 & 21.5 & 3.4 & 1400 & 7 \\
\hline Pirina Poljana polje & $42.6152^{\circ} \mathrm{N} 18.4127^{\circ} \mathrm{E}$ & 677 & 20.0 & 24.6 & 4370 & 5 \\
\hline Crkvice polje & $42.5406^{\circ} \mathrm{N} 18.6378^{\circ} \mathrm{E}$ & 848 & 19.0 & 2.1 & $2230^{\mathrm{a}}$ & 2 \\
\hline Unijerina polje & $42.5505^{\circ} \mathrm{N} 18.6512^{\circ} \mathrm{E}$ & 627 & 10.0 & 0.4 & $1930^{\mathrm{a}}$ & 11 \\
\hline Lipci fan & $42.4981^{\circ} \mathrm{N} 18.6556^{\circ} \mathrm{E}$ & 40 & 15.5 & - & 980 & 10 \\
\hline Kameno fan & $42.4904^{\circ} \mathrm{N} 18.5363^{\circ} \mathrm{E}$ & 622 & 8.0 & - & 150 & 7 \\
\hline Nudo valley & $42.6736^{\circ} \mathrm{N} 18.5704^{\circ} \mathrm{E}$ & 407 & 24.5 & - & 500 & 20 \\
\hline Sniježnice fan & $42.4971^{\circ} \mathrm{N} 18.5979^{\circ} \mathrm{E}$ & 1044 & 7.0 & - & 120 & 3 \\
\hline
\end{tabular}

a These sites lie within the MIS 12 ice limit and distances downstream refer to the MIS 6 ice margins. 
Instruments MC-ICPMS using standard procedures (Edwards et al., 1987). ${ }^{232}$ Th abundance was monitored for detrital correction. The U-series dates provide minimum ages for the fluvial depositional units and a basis for correlation with the glacial chronology of Hughes et al. (2010).

\section{Results: fluvial geomorphology, sedimentology, and geochronology}

There are three major depositional settings in the landscapes surrounding Mount Orjen: poljes, deeply incised bedrock valleys, and alluvial fans (Table 3). Each formed major surface meltwater pathways from the glaciated uplands during MIS 12 (Fig. 1) and are now filled with thick sequences of glacially derived coarse- and fine-grained limestone alluvium. Poljes are present across the Orjen region varying in size from 0.4 to $24.6 \mathrm{~km}^{2}$. Alluvial fans are well developed at the southern margins of the Orjen massif, either downstream of steep bedrock gorges (Lipci and Risan), or adjacent to the former ice margin (Kameno and Sniježnice). The river valley at Nudo is distinct because it is the only depositional setting around Orjen with a well-developed terrace sequence.

\subsection{The polje records}

Poljes are a major feature of the Mediterranean karst landscape especially across the Balkan Peninsula, and parts of Spain. They are flat-bottomed depressions bounded by steep slopes, typically extending over several hundred square kilometres (Gams, 1978; Ford and Williams, 1989, 2007, Fig. 2). Polje formation has been discussed in detail (Gams, 1978; Jennings, 1985; Ford and Williams, 1989, 2007; Nicod, 2003), but there has been little systematic study of their fluvial sedimentary fills. Over four decades ago Gams (1969) speculated that glacial-fluvial processes may have been important in the infilling of these basins, but there were no dates for Pleistocene glacial or fluvial records in the Mediterranean at this time and detailed investigations of the Pleistocene geology had not been carried out.

\subsubsection{The polje record beyond the Skamnellian Stage (MIS 12) glacial limit}

Five poljes have been investigated outside the maximum MIS 12 ice margins (Fig. 1; Table 3). These contain thick sequences of crudely-stratified coarse-grained gravels and sands. We have observed exposures $>10 \mathrm{~m}$ in thickness (Fig. 2b) but their full vertical extent is not known, (Gams, 2005). There is no evidence of buried soils or major erosional discontinuities within the outwash deposits of the poljes.

Pleistocene outwash was supplied to Dvrsno polje, northeast Orjen by two outlet glaciers (Fig. 1). The northern outlet glacier terminated within the polje, where a large moraine is now preserved (Hughes et al., 2010). The polje is filled with massive, coarsegrained alluvium, which becomes increasingly stratified and matrix-rich with distance from the ice margin (clast density decreases from $60 \%$ to $30 \%$ ). The southern outlet glacier, which was situated c $2.5 \mathrm{~km}$ from Dvrsno, would have drained into the polje via a bedrock gap at Han (Fig. 1). Here polje sediments are well stratified, and often cross-bedded, medium sands and granules with interstratified silts and clays. A $50 \mathrm{~cm}$-thick soil horizon at the polje surface (Fig. 3) yielded PDI values of 11.80 close to the ice margin, and 7.35 in the centre of the polje.

Glacial morphostratigraphic evidence and U-series ages suggest that Grahovo polje was also fed by two outlet glaciers during MIS 12 (Hughes et al., 2010). These terminated c $1.4 \mathrm{~km}$ from the polje and are separated from the depression by bedrock ridges. The massive, stratified sands and gravels resemble the sequence observed at
Dvrsno. Clasts are largely subangular to rounded pebbles and cobbles (clast density 50-60\%). A thin, sandy soil horizon has developed at the polje surface (PDI 9.91 and 4.76) and weak vadose calcite cements are frequently present on the underside of clasts (Fig. 3).

Kruševice, west Orjen, also contains thick sequences (up to $10 \mathrm{~m}$ ) of stratified, coarse-grained alluvium (Fig. 2c). Gravel and sandy silt lenses are abundant throughout the exposures and many are laterally continuous over several metres (Fig. 3). Sediments become increasingly stratified and fine-grained with distance from the former ice margin with an increase in clast roundness (angular to subangular). A $60 \mathrm{~cm}$-thick, yet frequently disturbed, soil horizon is present at the surface (PDI 13.75).

Pirina Poljana polje is located downstream of one of the largest ice lobes that emanated from the Orjen ice cap (Fig. 2d). Just inside the MIS 12 ice margins exposures present interstratified sands and gravels with a dominant silt matrix. A thin soil horizon at the surface yielded a PDI of 5.59. Beyond the maximum ice limits, poorly stratified coarse sands and gravels (subangular to subrounded, clast density 60\%) are dominant (Fig. 2). Well-stratified gravel horizons and interbedded fine sand and silt lenses are frequently present. The deposits are almost entirely weakly cemented with phreatic carbonate and a $60 \mathrm{~cm}$-thick soil horizon at the surface yielded a PDI of 9.12.

Vrbanje polje, west Orjen, is unique in that it lies beyond the MIS 12 ice margins but on the limestone plateau (>1000 $\mathrm{m}$ a.s.l.). This basin was fed by three separate ice lobes during MIS 12 and a series of smaller glaciers during MIS 6. Stratified to well-stratified clastand matrix-supported sands and gravels (clast density 20-60\%) predominate. Clasts are frequently blocky and faceted in morphology, which may indicate a glacial origin (Benn and Ballantyne, 1993, 1994), and some imbrication structures (NE flow direction) are present. A $30 \mathrm{~cm}$ thick granular and unconsolidated soil horizon has developed across the polje surface (PDI 4.88).

Four calcite samples from poljes outside the maximum (MIS 12) ice margins have been dated (Table 4). Secondary carbonate close to the surface of Grahovo polje (Sample G1) yielded an age of $>350 \mathrm{ka}$. Two samples from carbonate benches at Pirina Poljana are dated to $213.5 \pm 11.3 \mathrm{ka}(\mathrm{P} 1)$ and $77.2 \pm 2.0 \mathrm{ka}$ (P2). Sample P2 lies conformably immediately above the older cemented bench and suggests that this younger age may reflect more recent calcite formation within pre-existing sediments, and not a separate depositional phase. Calcite from the surface horizons at Vrbanje polje (V1) yielded an age of $126.6 \pm 4.5 \mathrm{ka}(\mathrm{V} 1)$.

\subsubsection{The polje record within the Skamnellian Stage (MIS 12) glacial limit}

The Crkvice and Unijerina poljes are situated on the eastern edge of the plateau, downstream of the MIS 6 moraines (Fig. 1). Sedimentary sequences are not as well-preserved as those outside the MIS 12 ice margins.

Two lithofacies have been identified at Crkvice. Section C1 contains a massive, matrix-supported diamicton with angular to subangular and faceted gravels (clast density 35\%). Weakly developed phreatic carbonates are present within some horizons and a granule-rich soil horizon has developed at the surface (PDI 3.92). Section C2 contains interstratified sands, gravels and fines (clast density typically $<60 \%$ ) which are comparable to the ice distal exposures of Dvrsno polje. Angular-subangular, blocky and faceted gravels present in the lowest horizons resemble those observed within Section C1. A $50 \mathrm{~cm}$-thick, weakly developed and granulerich soil horizon (PDI 4.12) is present at the surface (Fig. 3).

Three lithofacies have been identified within three exposures at Unijerina. The sediments are presented as a stacked sequence at Section U3 (Fig. 3). The lowest facies (U3a) contains a sequence of 

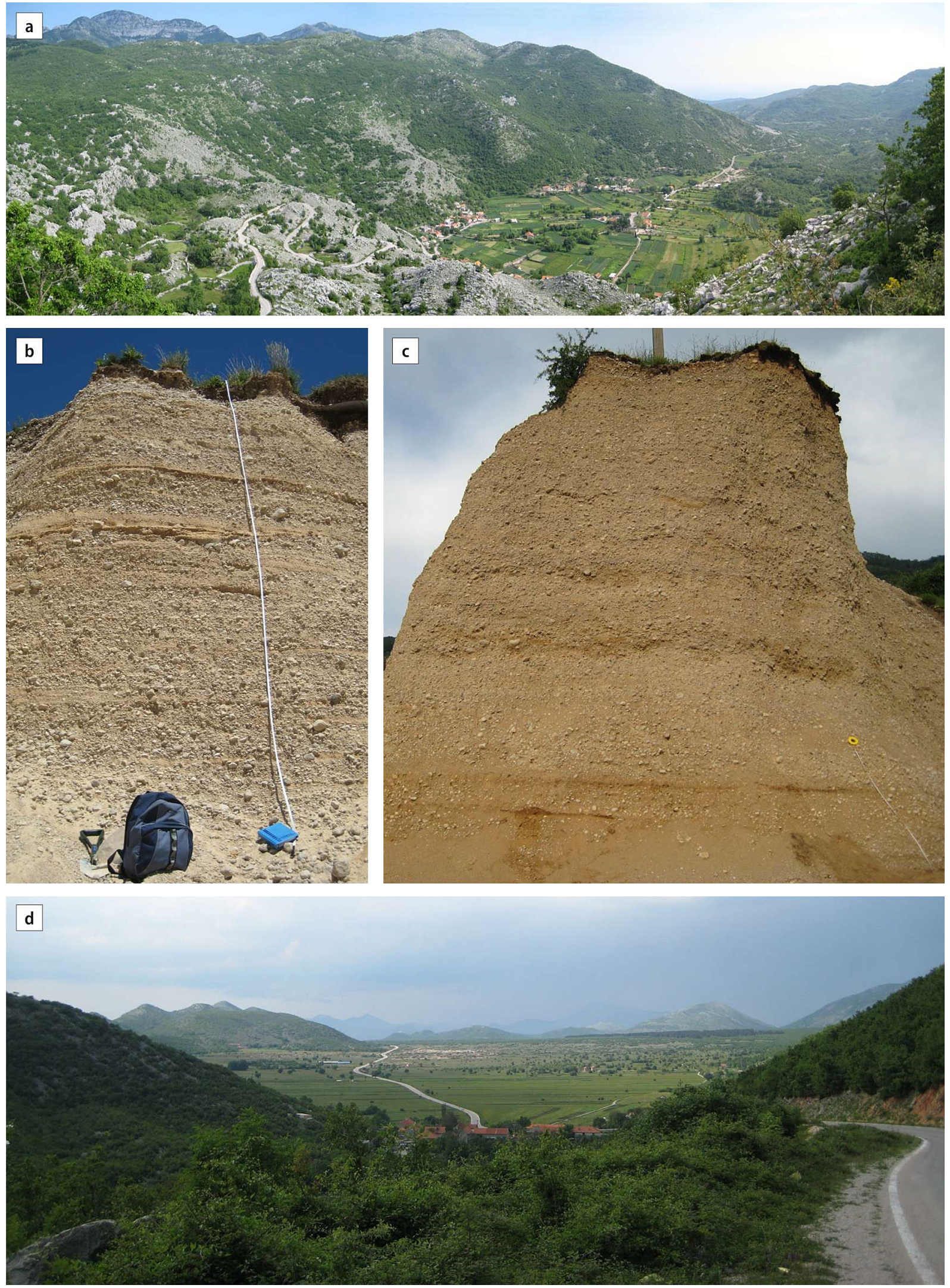

Fig. 2. The major poljes of Orjen at (a) Kruševice viewed from the plateau; (b) Dvrsno Section D5; (c) Kruševice Section Kr2; and (d) Pirina Poljana polje viewed from the border of Montenegro and Bosnia-Herzegovina. 


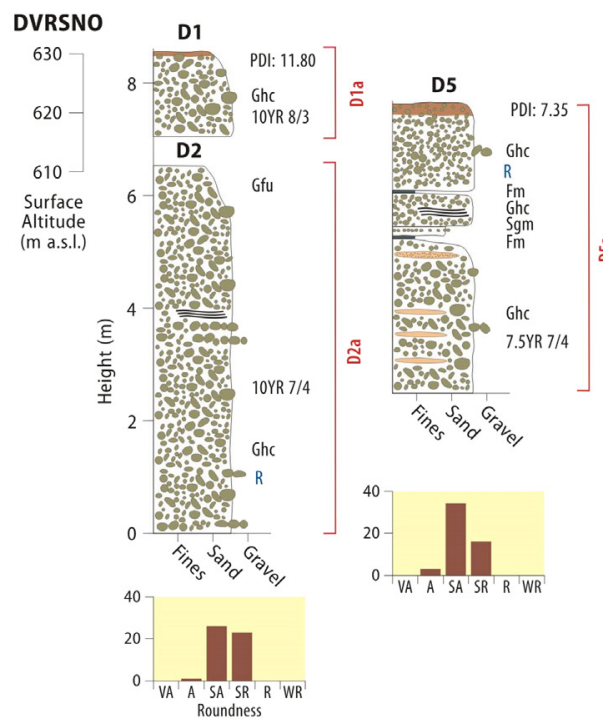

KRUŠEVICE

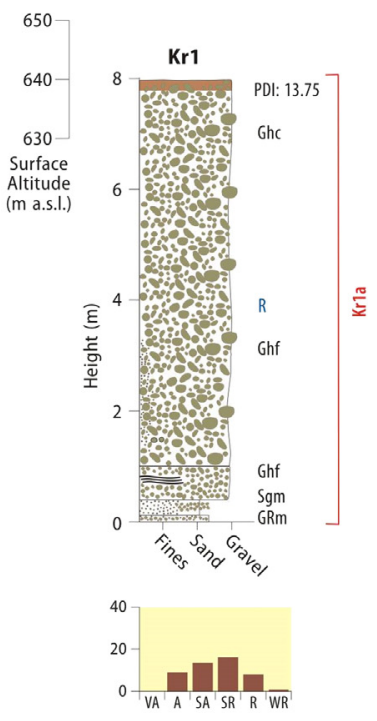

PIRINA

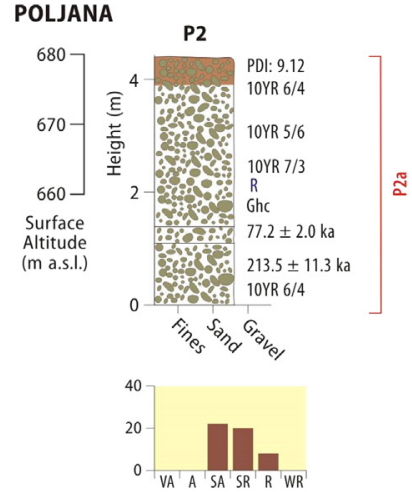

CRKVICE
VRBANJE

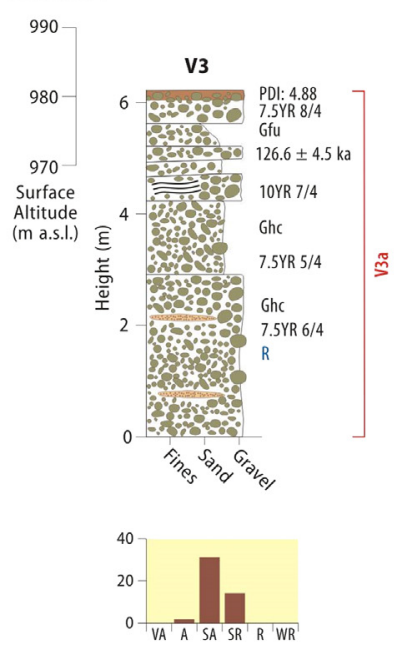

D9

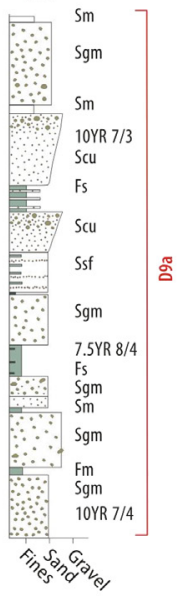

GRAHOVO

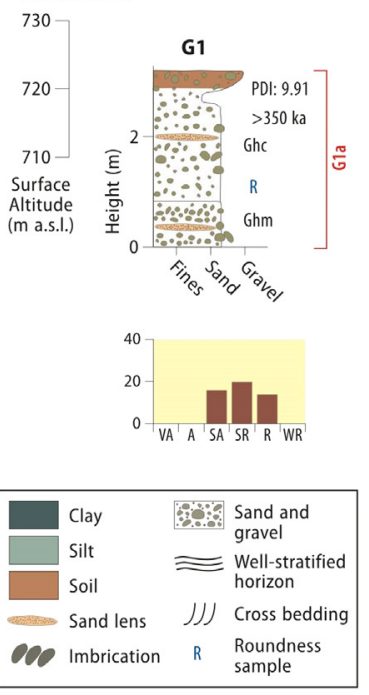

\section{UNIJERINA}
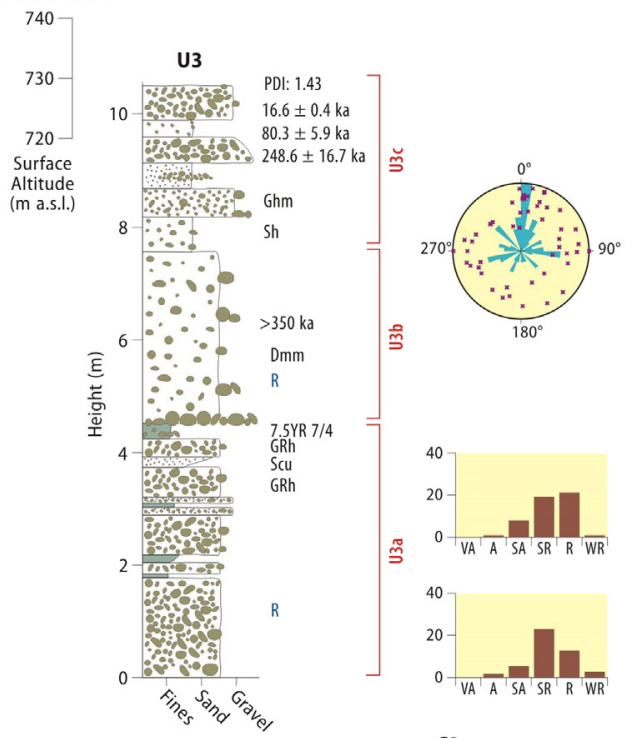

\section{Facies codes and descriptions}

Dmm Diamicton, matrix supported, massive

Fm Fine sand/silty layer, massive

Fines, interstratified

Gravels, coarsening upwards

Ghe Gravels, horizontally bedded, clast supported

Ghf Gravels, horizontally bedded, fine layers
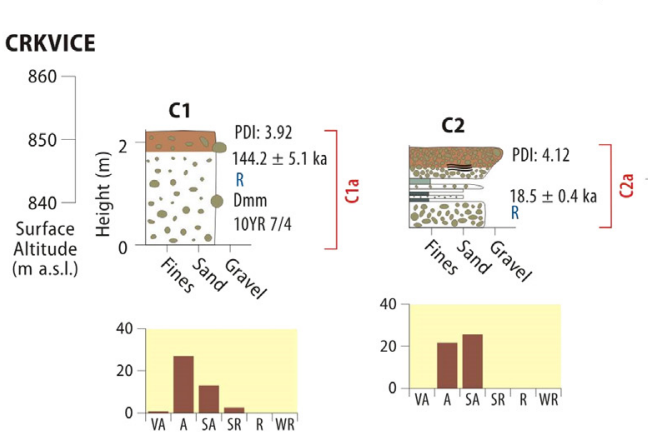

C2

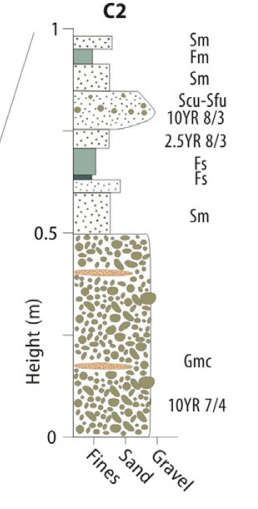

Fig. 3. Sedimentary sequences within the poljes surrounding Orjen. 
well-stratified alluvial gravels, sands and fines (typically subrounded to rounded granules and pebbles) which is capped by a massive sandy silt unit containing dropstones. This may be indicative of a slow flowing fluvial or shallow lacustrine environment (e.g. Rother et al., 2010; Alberti et al., 2011). This facies is overlain by a massive, matrix-supported (clast density 30-40\%), silt-rich diamicton (U3b) with blocky limestone clasts. Calcite rinds have been sampled for U-series dating. A granular soil at the diamict surface yields a PDI value of 6.29. The uppermost facies (U3iii) contains stratified, weakly cemented coarse sands and gravels (pebbles and cobbles; clast density 30-70\%). Three calcites have been sampled for U-series analysis, and a $60 \mathrm{~cm}$-thick, granule-rich soil has developed at the land surface (PDI 1.43).

Secondary carbonate from the stratified alluvium at Crkvice (section C2) yielded an age of $18.5 \pm 0.4 \mathrm{ka}$ (Table 4). A sample from the overlying diamict facies is dated to $144.25 .1 \pm 5.1 \mathrm{ka}(\mathrm{C} 1)$. This correlates with the U-series age from Vrbanje polje. Four samples from Unijerina have been dated. Calcite from the diamict facies yields an age of $>350 \mathrm{ka}$ (U1). Three samples from the overlying stratified alluvium provide ages of $248.6 \pm 16.7 \mathrm{ka}, 80.3 \pm 5.9 \mathrm{ka}$ and $16.6 \pm 0.4 \mathrm{ka}$ (U2-4; Table 4). These samples were extracted from adjacent calcite horizons, and it is likely that the younger ages reflect more recent carbonate formation within older sediments, deposited prior to $248.6 \pm 16.7 \mathrm{ka}$.

\subsection{The alluvial fan record}

Three alluvial fans have developed at the southern margins of the Orjen massif. The relatively shallow gradient alluvial fan at Lipci lies at the end of a deeply incised bedrock gorge. Massive to weakly stratified open framework gravels (dominantly subangular to subrounded cobbles; clast density $70-80 \%$ ) are exposed to depths of 6-8 $\mathrm{m}$ within a narrow channel (Fig. 4). The sediment matrix has been almost entirely displaced and is now strongly cemented by vadose zone and flowing water carbonates. Soil horizons are either absent or very poorly developed. A large fan at Risan also extends into the bay, but is mantled by unconsolidated scree and exposures are not present.

The upland alluvial fan at Kameno has formed downstream of a large lateral moraine complex that has been correlated to MIS 12 (Hughes et al., 2010). Exposures display massive, coarse-grained limestone sands and gravels (subangular to subrounded cobbles and boulders; clast density $80 \%$ ) which become finer and increasingly stratified down-fan (clast density 60-0\%). Sand lenses and interstratified silts/clays become increasingly dominant. Three calcite samples were taken for U-series dating from the fan apex (Fig. 4). A $60 \mathrm{~cm}$-thick, organic-rich surface soil horizon yielded a PDI value of 15.97. There is no evidence of buried soils or unconformities, which suggests that the sedimentary fill was deposited during a single aggradational phase.

At Sniježnice, south Orjen, sediments are exposed within shallow quarry cuttings into an ice marginal alluvial fan. The deposits display a typical ice marginal signature (Fraser and Cobb, 1982) of massive, clast-supported and poorly stratified sands and gravels (angular to subrounded; clast density 60\%) which become increasingly well stratified down-fan (Fig. 4). A $40 \mathrm{~cm}$ thick soil at the surface provided a PDI value of 2.51 .

A total of 11 secondary carbonates from the alluvial fans have been dated. Three samples close to the surface of the fan apex at Kameno yield ages $>350 \mathrm{ka}$. Seven samples from the coastal alluvial fan at Lipci yield ages from $320.6 \pm 33.3 \mathrm{ka}$ to $47.3 \pm 1.2 \mathrm{ka}$ (L1L7) (Table 4). These ages suggest that the bulk of the sedimentary sequence was deposited prior to c $320 \mathrm{ka}$. The youngest could be indicative of more recent alluviation phases during MIS 10-8, MIS 6 and MIS 5d-2. However, the close stratigraphic position of these calcites means that it is likely that these ages represent more recent phases of calcite formation within pre-existing alluvial sediments (see Woodward et al., 2004).

The secondary carbonate capping the outermost moraine and ice marginal alluvium at Sniježnice has been dated to $268.3 \pm 22.2 \mathrm{ka}(\mathrm{S} 1)$. The moraines here were correlated by Hughes et al. (2010) to MIS 6 on the basis of two U-series ages (102 and $124 \mathrm{ka}$ ) from calcite within the moraines. The Sniježnice fan is situated on the outer edge of a palimpsest of closely spaced moraines that appear to be widely separated in time. The fan may be associated with the largest glacial phase on Orjen during MIS 12, as the U-series age is a minimum age.

\subsection{The Nudo Valley terrace record}

Nudo valley, north Orjen, is a steep-sided limestone gorge. During the Pleistocene this valley would have drained the largest catchment on the Orjen massif (c $25 \mathrm{~km}^{2}$ ). This is the only basin with a well-developed series of terraces (Fig. 5). Six terrace surfaces have been identified, each capped by a $10-30 \mathrm{~cm}$ thick granular soil horizon (PDI of 1.84-6.29). The sediments are dominated by coarse-grained limestone gravels and sands (subrounded to subangular; clast density 50-60\%), and exposures can exceed $20 \mathrm{~m}$. Secondary carbonates have formed as cemented benches (Hamlin et al., 2000) and as rinds at clast surfaces. Six of these were sampled for U-series dating.

Three secondary carbonate samples, collected from various levels of the Zaslap, Javora and Vućiya units (N12-Z, N6-V and N8-J), yielded ages $>350 \mathrm{ka}$ (Fig. 5; Table 4) and indicate that a major phase of aggradation took place during MIS 12. Calcite from the lowest terrace (Zaslap Unit) also yielded an age of $146.8 \pm 9.1 \mathrm{ka}(\mathrm{N} 11-\mathrm{Z})$. Two samples from the highest terrace surface (Arandelovo Unit) are dated to $56.5 \pm 1.3 \mathrm{ka}$ (N5-A) and $65.9 \pm 5.2 \mathrm{ka}(\mathrm{N} 3-\mathrm{A})$ and may provide some evidence for later phases of aggradation during MIS 6 and perhaps also during MIS $5 \mathrm{~d}-2$. It is also possible (and perhaps more likely) that these ages reflect much more recent calcite formation within pre-existing (MIS 12) sediments.

\subsection{Alluvial chronostratigraphy}

On the basis of morpholithostratigraphy (cf Hughes et al., 2010) and the 27 U-series ages (Table 4) from the alluvial deposits surrounding Mount Orjen, two alluvial stratigraphical units have been identified on Mount Orjen: the Kotorska-Sušica Member and the Krivošije Member (Table 5). These broadly correspond to the Knezlaz (MIS 12) and Crkvice (MIS 6) members of the Orjen glacial stratigraphy (Hughes et al., 2010) as well as the glacial stratigraphy of the northwestern massifs of Montenegro (Hughes et al., 2011) and the Pindus Mountains of northwest Greece (Woodward et al., 2004; Hughes et al., 2006a). The uncorrected ages for each of the alluvial settings surrounding Orjen are presented here, following the method of Hughes et al. (2010). The corrected and uncorrected U-series ages are in close agreement, and only four samples yielded corrected ages outside the uncorrected error margins (Nudo $5-\mathrm{A}$, Vrbanje 1, Lipci 2 and Lipci 3).

The Kotorska-Sušica Member represents the most extensive phase of alluvial deposition at Orjen, and correlates with the Skamnellian Stage in Greece (MIS 12). It may also incorporate deposits from later cold stages between MIS 12 and 6 which remain formally undefined by glacial units in Greece and indeed the rest of the Balkans, despite limited evidence of MIS 8 glaciation from the Durmitor Massif in northwest Montenegro (Hughes et al., 2011). Useries ages and soil development indices from poljes, alluvial fans and river terraces indicate that the bulk of these sediments were 


\begin{tabular}{|c|c|c|c|c|c|c|c|c|c|c|c|c|c|c|c|}
\hline Sample name & ${ }^{238} \mathrm{U} \mathrm{ppm}$ & $\left({ }^{234} U /{ }^{238} U\right)$ & ${ }^{234} \mathrm{U} \mathrm{ppm}$ & ${ }^{230} \mathrm{Th} \mathrm{ppb}$ & ${ }^{232} \mathrm{Th} \mathrm{ppb}$ & $\left({ }^{230} \mathrm{Th} /{ }^{232} \mathrm{th}\right)$ & $\left({ }^{230} \mathrm{Th} /{ }^{234} \mathrm{U}\right)$ & $\begin{array}{l}\text { Uncorrected } \\
\text { age (years) }\end{array}$ & $2 \sigma$ uncertainty & \% Error & $\begin{array}{l}\left({ }^{234} \mathrm{U} /{ }^{238} \mathrm{U}\right) \\
\text { Corr }\end{array}$ & $\begin{array}{l}\left({ }^{230} \mathrm{Th} /{ }^{234} \mathrm{U}\right) \\
\text { Corr }\end{array}$ & $\begin{array}{l}\text { Corrected } \\
\text { age (years) }\end{array}$ & $\begin{array}{l}2 \sigma \\
\text { uncertainty }\end{array}$ & $\begin{array}{l}\% \\
\text { Error }\end{array}$ \\
\hline Lipci 1 & 0.035141 & 1.065922 & 0.000002 & 0.000359 & 1.446345 & 48.248427 & 0.585289 & 94,930 & -2949 & 3.09 & 1.066827 & 0.579956 & 93,551 & -4119 & 4.37 \\
\hline \pm & 0.000138 & 0.006056 & 0.000000 & 0.000004 & 0.261469 & 2.081015 & 0.006127 & 2918 & & & 0.008631 & 0.008644 & 4059 & & \\
\hline Lipci 2 & 0.048254 & 1.045114 & 0.000003 & 0.000496 & 17.297911 & 5.526309 & 0.600765 & 99,336 & -3005 & 3.01 & 1.051142 & 0.550013 & 86,455 & -3703 & 4.25 \\
\hline \pm & 0.000142 & 0.004719 & 0.000000 & 0.000005 & 3.126954 & 0.235034 & 0.005927 & 2972 & & & 0.007119 & 0.008138 & 3652 & & \\
\hline Lipci 3 & 0.040645 & 1.043621 & 0.000002 & 0.000245 & 37.096290 & 1.306583 & 0.352549 & 47,287 & -1237 & 2.61 & 1.062326 & 0.091213 & 10,434 & -384 & 3.67 \\
\hline \pm & 0.000116 & 0.004590 & 0.000000 & 0.000003 & 6.705850 & 0.056713 & 0.003787 & 1231 & & & 0.007664 & 0.001607 & 383 & & \\
\hline Lipci 4 & 0.044960 & 1.069242 & 0.000003 & 0.000711 & 0.976989 & 138.813735 & 0.903919 & 239,201 & $-14,203$ & 5.79 & 1.069741 & 0.903273 & 238,310 & $-20,095$ & 8.14 \\
\hline \pm & 0.000169 & 0.006305 & 0.000000 & 0.000007 & 0.176665 & 5.903630 & 0.008907 & 13,488 & & & 0.008953 & 0.012632 & 18,720 & & \\
\hline Lipci 5 & 0.093720 & 1.039572 & 0.000005 & 0.001529 & 5.408715 & 53.358399 & 0.958987 & 320,630 & $-33,318$ & 9.8 & 1.040337 & 0.958225 & 318,427 & $-47,462$ & 13.76 \\
\hline \pm & 0.000273 & 0.004923 & 0.000000 & 0.000015 & 0.977727 & 2.274448 & 0.009555 & 29,499 & & & 0.007034 & 0.013631 & 40,191 & & \\
\hline Lipci 6 & 0.069504 & 1.074016 & 0.000004 & 0.001036 & 0.601300 & 325.906693 & 0.848237 & 196,604 & $-10,170$ & 5.3 & 1.074227 & 0.847834 & 196,317 & $-14,471$ & 7.17 \\
\hline \pm & 0.000177 & 0.004188 & 0.000000 & 0.000011 & 0.108732 & 13.973645 & 0.008641 & 10,685 & & & 0.005933 & 0.012232 & 13,691 & & \\
\hline Lipci 7 & 0.054392 & 1.042278 & 0.000003 & 0.000875 & 9.338422 & 17.802572 & 0.943124 & 292,511 & $-26,580$ & 8.65 & 1.044807 & 0.939867 & 286,675 & $-37,228$ & 12.14 \\
\hline \pm & 0.000116 & 0.003870 & 0.000000 & 0.000009 & 1.688098 & 0.759053 & 0.009403 & 23,995 & & & 0.005643 & 0.013632 & 32,385 & & \\
\hline Kameno 1 & 0.172717 & 1.001775 & 0.000009 & 0.003195 & 44.714100 & 13.413989 & 1.128067 & $>350,000$ & & & 1.001940 & 1.13996 & $>350,000$ & & \\
\hline \pm & 0.000499 & 0.004445 & 0.000000 & 0.000030 & 8.082852 & 0.562676 & 0.010472 & & & & 0.006560 & 0.015615 & & & \\
\hline Kameno 2 & 0.107043 & 0.986860 & 0.000006 & 0.001776 & 0.794020 & 420.810674 & 1.027084 & & & & 0.986828 & 1.027151 & & & \\
\hline \pm & 0.000287 & 0.003932 & 0.000000 & 0.000017 & 0.143565 & 17.680394 & 0.009586 & & & & 0.005568 & 0.013575 & & & \\
\hline Kameno 3 & 0.186572 & 0.990173 & 0.000010 & 0.004064 & 39.670412 & 19.200662 & 1.343797 & & & & 0.989434 & 1.369917 & & & \\
\hline \pm & 0.000617 & 0.004604 & 0.000000 & 0.000047 & 7.171244 & 0.851279 & 0.015682 & & & & 0.006737 & 0.023413 & & & \\
\hline Grahovo 1 & 3.299652 & 0.995051 & 0.000177 & 0.053350 & 6.467664 & 1540.438851 & 0.992674 & $>350,000$ & & & & & $>350,000$ & & \\
\hline \pm & 0.011805 & 0.005328 & 0.000001 & 0.001811 & 1.169149 & 102.634402 & 0.033718 & & & & & & & & \\
\hline Pirina Poljana 1 & 0.608197 & 1.022929 & 0.000034 & 0.008791 & 81.214448 & 20.245668 & 0.863272 & 213,467 & $-11,337$ & & 1.023982 & 0.85714 & 208,739 & $-15,729$ & 7.32 \\
\hline & 0.001768 & 0.004664 & 0.000000 & 0.000084 & 14.680911 & 0.855687 & 0.008289 & 10,853 & & 5.2 & 0.006750 & 0.011898 & 14,820 & & \\
\hline Pirina Poljana 2 & 0.494590 & 1.018683 & 0.000027 & 0.004188 & 48.925047 & 16.044804 & 0.507855 & 77,162 & & & 1.019311 & 0.491622 & 73,634 & & \\
\hline \pm & 0.001518 & 0.005493 & 0.000000 & 0.000039 & 8.844061 & 0.673089 & 0.004720 & 1948 & -1961 & 2.53 & 0.007901 & 0.006568 & 2628 & -2653 & 3.59 \\
\hline Vrbanje 1 & 0.057041 & 1.005732 & 0.000003 & 0.000645 & 29.049695 & 4.158727 & 0.686823 & 126,552 & & & 1.006886 & 0.62426 & 106,635 & & \\
\hline \pm & 0.000152 & 0.004243 & 0.000000 & 0.000006 & 5.251233 & 0.174564 & 0.006395 & 4530 & -4148 & 3.43 & 0.006529 & 0.008935 & 4787 & -4874 & 4.53 \\
\hline Crkvice 1 & 0.179441 & 1.006803 & 0.000010 & 0.002170 & 2.326448 & 175.307302 & 0.733849 & 144,153 & & & 1.006832 & 0.732717 & 143,675 & & \\
\hline \pm & 0.000476 & 0.004000 & 0.000000 & 0.000020 & 0.420558 & 7.324785 & 0.006688 & 4969 & -5067 & 3.48 & 0.005670 & 0.009464 & 6971 & -7165 & 4.92 \\
\hline Crkvice 2 & 1.081247 & 1.024392 & 0.000060 & 0.002834 & 35.792257 & 14.867744 & 0.156331 & 18,547 & & & 1.024660 & 0.14727 & 17,381 & & \\
\hline \pm & 0.004055 & 0.005157 & 0.000000 & 0.000029 & 6.470095 & 0.637815 & 0.001600 & 408 & -409 & 2.2 & 0.007334 & 0.002143 & 541 & -542 & 3.12 \\
\hline Nudo 3 - A & 0.891523 & 1.017869 & 0.000049 & 0.006738 & 65.642251 & 19.193550 & 0.453634 & 65,855 & & & 1.018313 & 0.440322 & 63,234 & & \\
\hline \pm & 0.003036 & 0.005077 & 0.000000 & 0.000194 & 11.866407 & 1.179555 & 0.013061 & 5057 & -5165 & 7.76 & 0.007271 & 0.018147 & 6838 & -7036 & 10.97 \\
\hline Nudo 5 - A & 0.620712 & 1.002395 & 0.000034 & 0.004195 & 286.131453 & 2.743638 & 0.411891 & 56,525 & & & 1.002823 & 0.307118 & 40,057 & & \\
\hline \pm & 0.001980 & 0.004931 & 0.000000 & 0.000042 & 51.723070 & 0.117023 & 0.004115 & 1333 & -1340 & 2.36 & 0.007523 & 0.00468 & 1432 & -1438 & 3.58 \\
\hline Nudo $6-\mathrm{V}$ & 0.849318 & 0.994524 & 0.000046 & 0.014187 & 64.184684 & 41.298423 & 1.026098 & $>350,000$ & & & 0.998705 & & $>350,000$ & & \\
\hline \pm & 0.001194 & 0.004172 & 0.000000 & 0.000139 & 11.602457 & 1.754760 & 0.010087 & & & & 0.007112 & & & & \\
\hline Nudo 8 - J & 1.026203 & 0.998719 & 0.000055 & 0.016688 & 34.340062 & 90.821308 & 0.994726 & $>350,000$ & & & 1.004641 & 0.994667 & $>350,000$ & & \\
\hline \pm & 0.003452 & 0.005001 & 0.000000 & 0.000451 & 6.209217 & 5.423918 & 0.026899 & & & & 0.006966 & 0.038249 & & & \\
\hline Nudo $11-Z$ & 0.586691 & 1.003992 & 0.000032 & 0.007133 & 249.381977 & 5.350506 & 0.739851 & 146,778 & -9092 & 6.08 & 1.005877 & 0.697777 & 130,459 & $-11,320$ & 8.49 \\
\hline \pm & 0.001854 & 0.004591 & 0.000000 & 0.000109 & 45.080171 & 0.256620 & 0.011318 & 8768 & & & 0.007098 & 0.016185 & 10,823 & & \\
\hline Nudo $12-\mathrm{Z}$ & 0.328534 & 1.005662 & 0.000018 & 0.005761 & 36.519369 & 29.536650 & 1.065251 & $>350,000$ & & & & 1.067712 & $>350,000$ & & \\
\hline \pm & 0.001089 & 0.004927 & 0.000000 & 0.000053 & 6.601527 & 1.237108 & 0.009823 & & & & & 0.014181 & & & \\
\hline Unijerina 1 & 1.178867 & 1.005373 & 0.000064 & 0.020278 & 206.633313 & 18.336884 & 1.045235 & $>350,000$ & -5863 & 7.22 & 1.005701 & 1.047986 & $>350,000$ & -8138 & 10.21 \\
\hline \pm & 0.003646 & 0.004523 & 0.000000 & 0.000281 & 37.352759 & 0.853089 & 0.014485 & & & & 0.006586 & 0.021139 & & & \\
\hline Unijerina 2 & 0.334505 & 1.009957 & 0.000018 & 0.002881 & 17.207791 & 31.440809 & 0.521029 & 80,256 & & & 1.010128 & 0.51287 & 78,416 & & \\
\hline \pm & 0.001151 & 0.005531 & 0.000000 & 0.000072 & 3.110615 & 1.814506 & 0.013054 & 5725 & & & 0.007889 & 0.018326 & 7871 & & \\
\hline Unijerina 3 & 0.541709 & 0.969782 & 0.000028 & 0.001210 & 4.354443 & 52.741709 & 0.140747 & 16,577 & -360 & 2.17 & 0.969702 & 0.138399 & 16,279 & -500 & 3.07 \\
\hline \pm & 0.001708 & 0.004648 & 0.000000 & 0.000012 & 0.787142 & 2.258482 & 0.001430 & 360 & & & 0.006582 & 0.001991 & 499 & & \\
\hline Unijerina 4 & 0.294718 & 1.008743 & 0.000016 & 0.004378 & 38.902517 & 21.090755 & 0.899563 & 248,628 & $-16,690$ & 6.49 & 1.009140 & 0.895047 & 243,876 & $-23,301$ & 9.14 \\
\hline
\end{tabular}


deposited prior to $350 \mathrm{ka}$. This phase of widespread aggradation correlates with the major glaciation of Orjen during MIS 12 when ice extended beyond the plateau and large volumes of glacigenic sediment would have been delivered to the fluvial systems downstream. It is important to emphasise that nine of the 10 sites that contain sediments belonging to the Kotorska-Sušica Member either contain U-series ages or strongly developed soils (PDI $>5.00$ ) that indicate deposition during MIS 12 (Table 5). At just one site, Sniježnice, soils yielded a low PDI (2.52) and also provided a U-series age of $268.3 \pm 22.2 \mathrm{ka}$. However, it is important to remember that these U-series ages provide minimum ages for sediment deposition and land surface stability, and it is likely, given the stratigraphical context, that several ages reflect much more recent calcite development within pre-existing (MIS 12) sediments (Woodward et al., 2004). Some of the soil PDI values, which range from 1.43 to 15.98 , may suggest that this member contains a collection of diachronous units where land surface stabilisation and the onset of soil development have been spatially variable. However, the absence of buried soils and sediment discontinuities within the thick sedimentary sequences surrounding Orjen, as well as a number of U-series ages $>350 \mathrm{ka}$, suggests that the bulk of the alluvial material was deposited in association with the major glacial phase of MIS 12 (see Table 5). These settings did not undergo multiple phases of erosion, deposition, and stabilisation. This contrasts with Pleistocene sedimentary sequences found elsewhere in the Balkans, where limestone-rich parent materials have been exposed to pedogenic weathering processes, and thick red-brown soils are produced (Woodward et al., 1994).

Deposits of the Krivošije Member are largely limited to the high altitude plateau, at Crkvice (144.2 $\pm 5.1 \mathrm{ka})$ and Vrbanje $(126.6 \pm 4.5 \mathrm{ka})$ poljes, and correlate with the Vlasian Stage (MIS 6) of the glacial chronostratigraphy of Greece (Hughes et al., 2006a). The alluvial sediments at these sites represent only a thin veneer at the polje surface and it is likely that these deposits are underlain by MIS 12 sediments (Kotorska-Sušica Member). Beyond the upland massif, and downstream of the MIS 12 moraines, there is only very limited evidence of MIS 6 alluvium. U-series ages from Pirina Poljana polje (77.2 $\pm 2.0 \mathrm{ka})$, Nudo valley (146.8 $\pm 9.1 \mathrm{ka})$, and Lipci alluvial fan (196.6 $\pm 10.8 \mathrm{ka} ; 99.3 \pm 3.1 \mathrm{ka}$ and $94.9 \pm 2.10 \mathrm{ka})$ may indicate a depositional phase at this time, but this is not supported by the morphostratigraphical evidence.

Alluvium from the last cold stage (Tymphian Stage in the Greece glacial chronostratigraphy encompassing MIS $5 \mathrm{~d}-2$ and the Younger Dryas) has not yet been observed within the fluvial record of Mount Orjen. Two secondary carbonate samples dated to $18.5 \pm 0.4$ (Crkvice polje) and $16.6 \pm 0.4$ (Unijerina valley) may reflect some MIS 5d-2 deposition (correlated to the Gornji do and Reovci Members of the glacial record). These dated calcites were obtained from horizons stratigraphically above calcites that have yielded much older ages, and it is likely that the younger ages represent calcite development within pre-existing (MIS 12) sediments. This chronological unit has therefore not been assigned a formal morphostratigraphical subdivision. It is likely that at least some of the dolines on the higher altitude plateau surfaces are filled with outwash sediments from MIS 6 and MIS 5d-2, but exposures have not been found.

\section{Discussion}

\subsection{Long-term coupling of glacial and fluvial systems}

The alluvial record of Orjen is out of step with many existing records of long-term river behaviour in the Mediterranean because Late Pleistocene river deposits tend to be much better preserved (Macklin et al., 2002; Fontana et al., 2008; Woodward et al., 2008). 

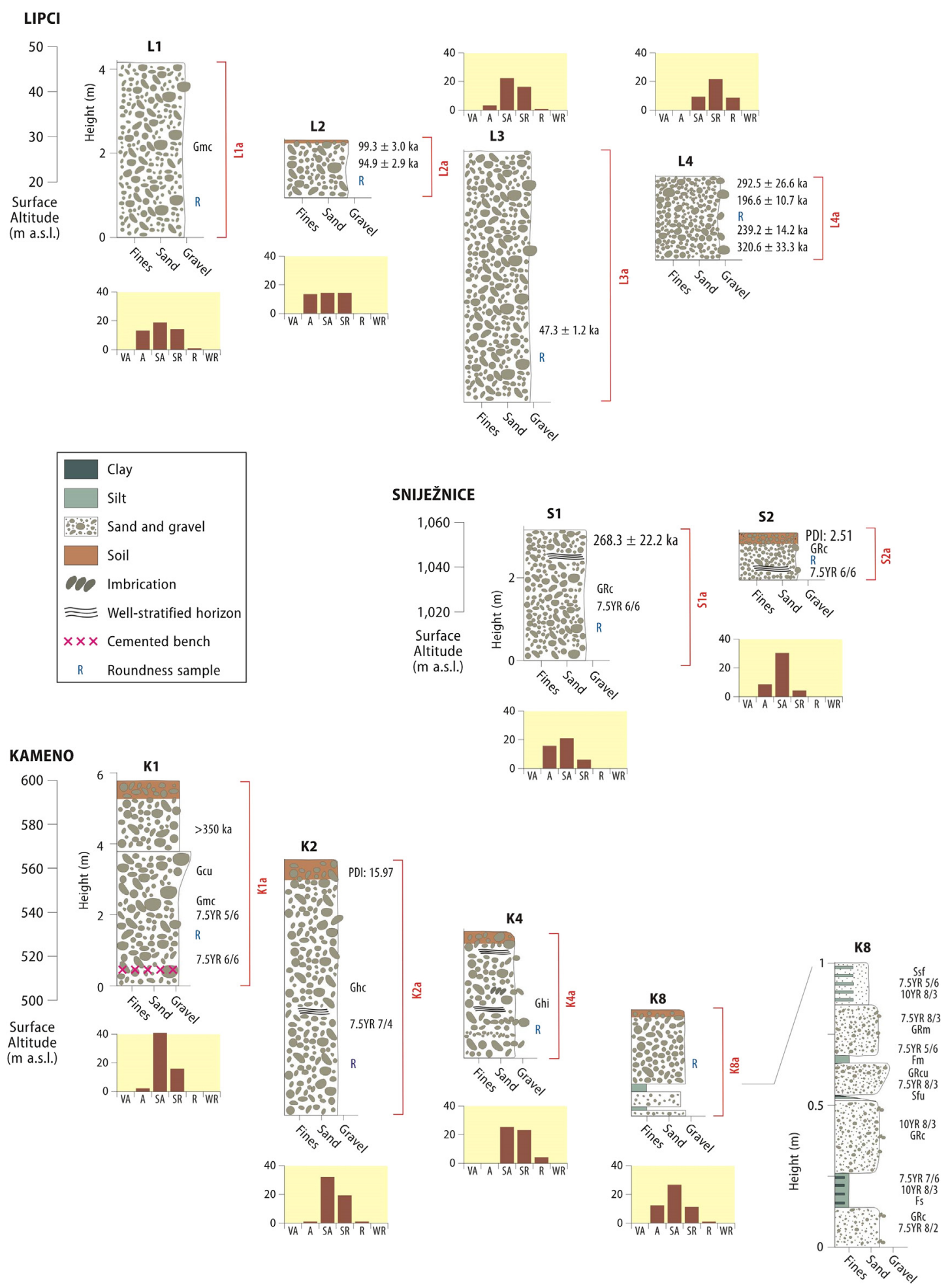

Fig. 4. Sedimentary sequences within alluvial fans, south Orjen. See Fig. 3 for legend and lithofacies codes. See Fig. 3 for facies codes.

The Orjen record is distinct because it is dominated by a major phase of aggradation from MIS 12 and there is only limited evidence of aggradation in later depositional phases. During MIS 12, ice extended across the plateau ( $>58 \%$ coverage; Table 2 ) and into the surrounding basins $(<1000 \mathrm{~m}$ a.s.l.) which received very large sediment fluxes from meltwater floods. The glacial and fluvial systems were strongly coupled (Fig. 6) and a highly efficient meltwater and sediment transfer system was established. All of the exposures we have recorded are dominated by cobble gravels with a sandy to silt matrix and all components of the alluvial record are formed from limestone-derived sediments. The abundance of carbonate-rich silts in the fine matrix of the outwash gravels is indicative of comminution processes in a glacial environment (Woodward et al., 1992a,b). 


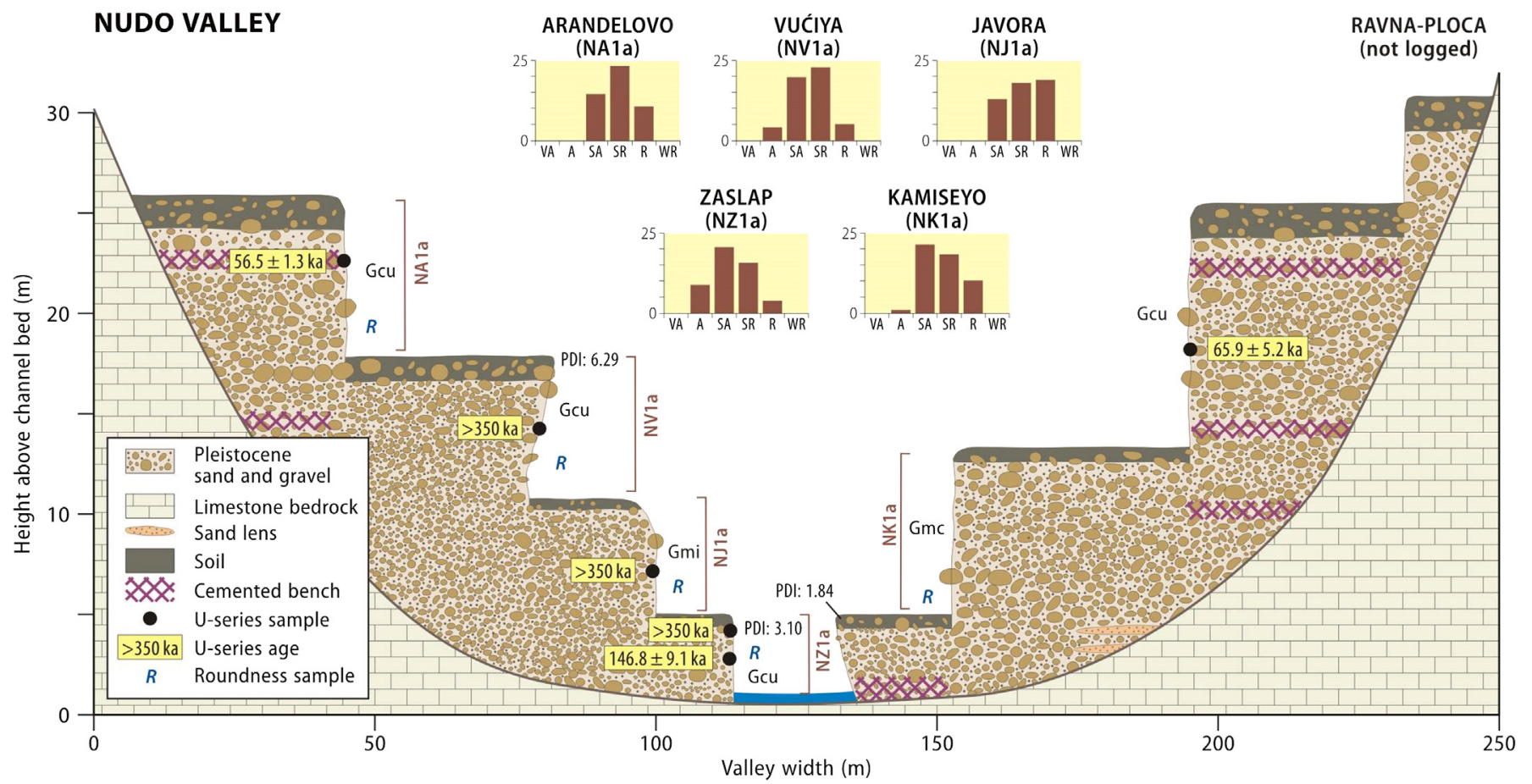

Fig. 5. Channel cross-section and sedimentary characteristics of the Nudo valley fill, north Orjen. See Fig. 3 for facies codes.

U-series ages from secondary carbonates close to the surface of these exposures have yielded ages consistent with a major phase of deposition during the Middle Pleistocene before $350 \mathrm{ka}$. The absence of buried soils, weathering horizons, and major unconformities points to a major and sustained phase of alluvial deposition which correlates with the most extensive glaciation of
MIS 12. The glaciations that followed MIS 12 were much reduced in volume and extent. Ice became increasingly constrained to higher elevations and extensive areas of karst were exposed on the plateau. Coupling between the glacial and fluvial system became weaker, creating a much less efficient sediment delivery system. During MIS $6,>65 \%$ of the karst plateau was ice free (Table 2). We

Table 5

The alluvial chronostratigraphy of Mount Orjen with the glacial chronostratigraphy developed by Hughes et al. (2010).

\begin{tabular}{|c|c|c|c|c|c|c|}
\hline Unit & Member & Exposures & Soil PDI & U-series age (ka) & MIS & Glacial record (Hughes et al., 2010) \\
\hline \multirow[t]{3}{*}{2} & Krivošije Member & Vrbanje & 4.88 & $126.5 \pm 4.5$ & 6 & Crkvice Member \\
\hline & & Crkvice & 3.92 & $144 \pm 5.1$ & & \\
\hline & & & 4.12 & $18.5 \pm 0.4$ & & \\
\hline \multirow[t]{26}{*}{1} & Kotorska-Sušica Member & Dvrsno & 7.35 and 11.80 & - & $12-8^{\mathrm{a}}$ & Knezlaz Member \\
\hline & & Grahovo & 8.91 & $>350$ & & \\
\hline & & Kruševice & 13.75 & - & & \\
\hline & & Vrbanje & 4.88 & - & & \\
\hline & & Pirina Poljana & 5.59 and 9.12 & $213 \pm 11.3$ & & \\
\hline & & & & $77.2 \pm 2.0$ & & \\
\hline & & Nudo Arandelovo & - & $65.9 \pm 5.2$ & & \\
\hline & & & & $56.5 \pm 1.3$ & & \\
\hline & & Nudo Vućiya & 6.29 & $>350$ & & \\
\hline & & Nudo Kamiseyo & - & - & & \\
\hline & & Nudo Javora & - & $>350$ & & \\
\hline & & Nudo Zaslap & 1.84 & $>350$ & & \\
\hline & & & 3.1 & $146.8 \pm 9.1$ & & \\
\hline & & Kameno & 15.97 & $>350$ & & \\
\hline & & Lipci & - & $320.6 \pm 33.4$ & & \\
\hline & & & & $292.5 \pm 26.7$ & & \\
\hline & & & & $239.2 \pm 14.2$ & & \\
\hline & & & & $196.6 \pm 10.8$ & & \\
\hline & & & & $99.3 \pm 3.1$ & & \\
\hline & & & & $94.9 \pm 2.10$ & & \\
\hline & & & & $47.3 \pm 1.3$ & & \\
\hline & & Unijerina & 6.29 & $>350$ & & \\
\hline & & & 1.43 & $248.6 \pm 16.7$ & & \\
\hline & & & & $80.3 \pm 5.9$ & & \\
\hline & & & & $16.6 \pm 0.4$ & & \\
\hline & & Sniježnice $^{\mathrm{a}}$ & 2.51 & $268.3 \pm 22.2$ & & \\
\hline
\end{tabular}

\footnotetext{
${ }^{a}$ It is likely that this Member is dominated by MIS 12 sediments. See Section 4.4 for discussion.
} 

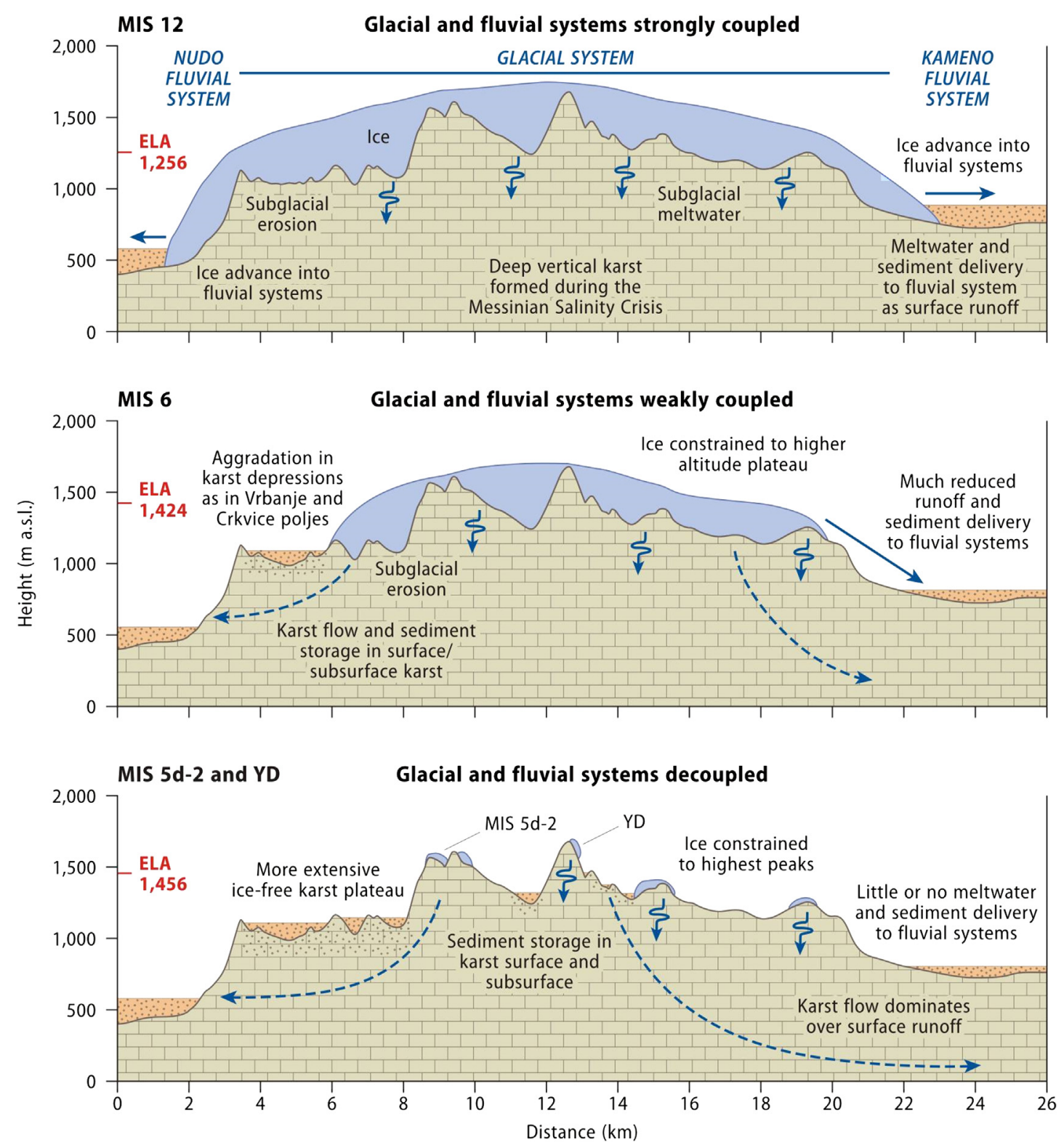

Fig. 6. Schematic diagram of the influence of the karst landscape on the deposition and preservation of the Middle Pleistocene alluvial records surrounding Orjen.

have the clearest evidence of fluvial deposition during MIS 6 at just two sites, Vrbanje and Crkvice. It is significant that both are small poljes located on the edge of the karst plateau. Sediment fluxes were much lower than those of MIS 12 with fluvial sediments discharging into sinkholes and retained within karst depressions on the plateau. The distal alluvial depocentres surrounding the plateau were only very weakly coupled, if at all, to the glacial system at this time (Fig. 6). During MIS 5d-2 cirque and valley glaciers were confined to the highest peaks, exposing a much greater extent (>99.5\%) of the upland karst surface (Table 2, Fig. 6). Sediment generation from these small glaciers would have been dramatically reduced. Subterranean flows assumed even greater dominance over surface runoff throughout the last cold stage. Coupling between the glacial realm and the adjacent alluvial basins beyond the plateau by surface flows was absent at this time (Fig. 6).

While there are multiple U-series ages from later periods (Table 5), morpholithostratigraphic evidence of glaciofluvial deposition later than MIS 12 in any of the depocentres beyond the plateau is effectively absent (Table 6). A series of ages correlated to MIS 5d-2 (Nudo), may represent deposition during the last cold stage, but this is not supported by sedimentological evidence, and the dates may reflect more recent calcite formation within preexisting (MIS 12 or 6) sediments. It is also possible that these younger ages, as well as those at Crkvice (MIS 6) and Vrbanje (MIS 6-5e), reflect the long-term, or paraglacial, redistribution of glacially prepared sediment (Church and Ryder, 1972; Ballantyne, 2002; Woodward et al., 2008). In addition to karst processes, it is likely that sub-glacial erosion of the plateau created depressions that provided important accommodation space for glaciofluvial sediments after MIS 12 (Dühnforth et al., 2008). Periglacial weathering during the cold stages of the Pleistocene may have also enhanced the formation of karst depressions and led to increased sediment production and delivery into these depocentres. Periglacial weathering has been suggested as a significant mechanism 
Table 6

Summary of the Pleistocene alluvial records surrounding Mount Orjen. See Fig. 1 for locations. Ticks indicate morpholithostratigraphical evidence of fluvial deposition. Maximum U-series ages at each site are indicated.

\begin{tabular}{|c|c|c|c|c|c|}
\hline \multirow[t]{2}{*}{ Site and context } & \multicolumn{3}{|c|}{$\begin{array}{l}\text { Alluvium present from } \\
\text { marine isotope stage: }\end{array}$} & \multirow[t]{2}{*}{$\begin{array}{l}\text { Maximum } \\
\text { U-Series age (ka) }\end{array}$} & \multirow[t]{2}{*}{$\begin{array}{l}\text { Evidence } \\
\text { of incision? }\end{array}$} \\
\hline & 12 & 6 & 2 & & \\
\hline Grahovo Polje & $\nu$ & & & $>350$ & \\
\hline Vrbanje Polje & $\nu$ & 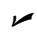 & & $126.5 \pm 4.5$ & \\
\hline Pirina Poljana Polje & $\nu$ & & & $213.5 \pm 11.3$ & \\
\hline Crkvice Polje & $\nu$ & 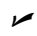 & & $126.5 \pm 4.5$ & \\
\hline Unijerina Polje & 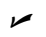 & & & $248.6 \pm 16.7$ & \\
\hline Lipci Fan & $\nu$ & & & $>350$ & $\nu$ \\
\hline Kameno Fan & 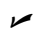 & & & $>350$ & \\
\hline Sniježnice Fan & $\nu$ & & & $268.3 \pm 22.2$ & \\
\hline Nudo Valley & $\nu$ & & & $>350$ & r \\
\hline
\end{tabular}

of sediment preparation and transportation in other glaciated basins of the Mediterranean (e.g. Bini and Zuccoli, 2004; Castiglioni, 2004).

The decrease in glacial extent, a reduced sediment flux, and an increase in the area of exposed upland karst, resulted in the connectivity between the glacial system and the valleys surrounding Mount Orjen becoming progressively weaker. The deep karst network provided the dominant pathway for meltwater and sediment transport during the cold stages that followed MIS 12. As we have shown, some of this sediment was also retained within surface dolines, poljes, and sinkholes. The transfer of Pleistocene glaciofluvial sediments through subterranean karst has been reported in Colorado (Burger, 2004), Tasmania (Kiernan et al., 2001), and Croatia (Bočić et al., 2012), but has not previously been assessed over several glacial cycles. Analysis of the Pleistocene glacial and fluvial deposits of Orjen allows us to more fully understand the impacts of karst terrain on long-term land surface processes. During interglacials the karst network provides the dominant route for runoff.

\subsection{The contrasting alluvial settings of Mount Orjen}

The increasing dominance of karst drainage over surface channel flows since the Middle Pleistocene has limited the extent of both deposition and incision during later cold (and warm) stages. Apart from the Nudo Valley and shallow channel cuttings into the Lipci fan, there is very little evidence of large-scale incision into the Middle Pleistocene (MIS 12) alluvial record and, in most cases, modern surface channel systems are very poorly developed or absent. This may be partly a function of the radial drainage pattern of Orjen, where meltwater was divided into at least 10 small surface catchments. Interestingly, this contrasts strongly with the Pleistocene alluvial record from the Voidomatis River basin in northwest Greece (Woodward et al., 2008) where most of the meltwater from the glaciated karst uplands (and rainfall-generated floodwater during interglacials) was channelled through a single valley. Today, surface runoff is limited, as waters are preferentially channelled into the subterranean karst - Nudo is the only valley that conveys large flood discharges in an alluvial channel. U-series ages and soil PDIs from the Nudo river terraces indicate a major phase of deposition prior to $350 \mathrm{ka}$ (MIS 12). This is consistent with the depositional history of the large poljes at Grahovo and Pirina Poljana, Kameno and Lipci alluvial fans and Sniježnice, which also suggest that maximum alluviation occurred during MIS 12. This valley drained the largest ice lobe during MIS 12 and some of the largest glaciers during MIS 6 (Fig. 1). Unlike the shallow topography of the poljes, the steep-sided limestone gorges of Nudo favoured the channelling of high-energy meltwater floods. This has formed a deeply incised terrace sequence with exposures in the Pleistocene alluvium exceeding $20 \mathrm{~m}$ (Fig. 5).

The polje records around Mount Orjen do not record the glacial-interglacial pattern of aggradation and incision seen in other Mediterranean Pleistocene fluvial systems (Macklin et al., 2002; Dühnforth et al., 2008; Fontana et al., 2008; Rother et al., 2010). These poljes became filled with thick sequences of alluvium during the major glacial phase of MIS 12 . There is only limited evidence of alluvial sedimentation in later cold stages (MIS 6 or 5d2 ). Since MIS 12, the large poljes beyond the Orjen massif have not been overrun by ice and the Middle Pleistocene alluvial sequences remain largely intact (Fig. 6). This is a striking feature of the Quaternary landscape. These poljes form some of the best-preserved records of Middle Pleistocene alluvial sedimentation in the Mediterranean (Macklin et al., 2002; Macklin and Woodward, 2009).

\section{Conclusions}

Detailed field investigations and U-series dating on and around Mount Orjen have revealed a Pleistocene alluvial record dominated by sediment delivered before 350 ka during the major glacial phase of MIS 12. This was a period of major landscape change and sediment delivery within this part of the Mediterranean. There is only very limited evidence of alluvial deposition during later cold stages, despite clear records of glaciation during MIS 6, 5d-2, and the Younger Dryas.

The karst system has exerted a major control on the development and preservation of the alluvial sedimentary record. After MIS 12 , ice extent was much reduced and limited to the plateau so that meltwater and outwash sediments were preferentially diverted into karst conduits. The sedimentary records of the Orjen cave system have not yet been analysed in detail. It is likely that karst systems within other glaciated limestone catchments contain valuable records of Pleistocene landscape dynamics (e.g. Bočić et al., 2012).

The long-term uncoupling between sediment source and downstream surface sinks reflects both the decrease in the magnitude of the glaciations (and the concomitant decline in water and sediment flux) and the progressive dominance of the deep subterranean karst drainage systems. This behaviour can usefully be added to Schumm's (1977) classic model of the fluvial system for these catchment types.

\section{Acknowledgements}

The authors would like to thank Peter van Calsteren and Louise Thomas at the Open University Uranium-Series Laboratory for their guidance with Uranium-series sample preparation and analysis. We would also like to thank the reviewers and editorial team for their very constructive comments, all of which have considerably enhanced the quality of this paper.

\section{References}

Alberti, A.P., Díaz, M.V., Martini, I.P., Pascucci, V., Andreucci, S., 2011. Upper Pleistocene glacial valley-junction sediments at Pias, Trevinca Mountains, NW Spain. In: Geological Society of London, Special Publications, vol. 354, pp. 93-110.

Ballantyne, C.K., 2002. Paraglacial geomorphology. Quat. Sci. Rev. 21, 1935-2017.

Benn, D.I., Ballantyne, C.K., 1993. The description and representation of particle shape. Earth Surf. Process. Landforms 18, 665-672.

Benn, D.I., Ballantyne, C.K., 1994. Reconstructing the transport history of glacigenic sediments: a new approach based on the co-variance of clast form indices. Sediment. Geol. 91, 215-222.

Bini, A., Zuccoli, L., 2004. Glacial history of the Southern side of the central Alps, Italy. In: Ehlers, J., Gibbard, P.L. (Eds.), Quaternary Glaciations - Extent and Chronology Part 1: Europe. Elsevier, Amsterdam, pp. 95-200.

Birkeland, P.W., 1999. Soils and Geomorphology, third ed.. Oxford University Press, New York. 
Bočić, N., Faivre, S., Kovaičić, M., Horvatinčić, N., 2012. Cave development under the influence of Pleistocene glaciation in the Dinarides - an example from Śtirovača Ice Cave (Velebit Mt., Croatia). Z. Geomorphol. 56 (4), 409-433.

Bortoluzzi, G., Del Bianco, F., D’Oriano, F., Giglio, F., Borgia, T.T.M., Santi, D., Bulatović, A., Dević, N., Radojević, D., Matović, M., Sretenović, A., Diaconov, A. Tola, M., 2009. Report on the Morphobathymetric, Oceanographic, Geological and Geophysical Investigations During Cruise MNG01 09 (19-27 April 2009, R/V Urania). ISMAR-CNR Interim Technical Cruise Report Bologna.

Bridgland, D.R., Demir, T., Seyrek, A., Pringle, M., Westaway, R., Beck, A.R., Rowbotham, G., Yurtmen, S., 2007. Dating quaternary volcanism and incision by the River Tigris at Diyarbakır, southeast Turkey. J. Quat. Sci. 22 (4), 387-393.

Burger, P.A., 2004. Glacially-influenced sediment cycles in the Lime creek karst, Eagle County, Colorado. In: Sasowsky, I.D., Mylroie, J. (Eds.), Studies of Cave Sediments: Physical and Chemical Records of Paleoclimate. Kluwer Academic/ Plenum Publishers.

Calvet, M., Delmas, M., Gunnell, Y., Braucher, R., Bourlès, D., 2011. Recent advances in research on quaternary glaciations in the Pyrenees. In: Ehlers, J., Gibbard, P.L., Hughes, P.D. (Eds.), Quaternary Glaciations - Extent and Chronology: A Closer Look. Elsevier, Amsterdam, pp. 127-140.

Candy, I., Black, S., Sellwood, B.W., 2004. Quantifying time scales of pedogenic calcrete formation using U-series disequilibria. Sediment. Geol. 170, 177-187.

Castiglioni, G.B., 2004. Quaternary glaciations in the eastern sector of the Italian Alps. In: Ehlers, J., Gibbard, P.L. (Eds.), Quaternary Glaciations - Extent and Chronology Part 1: Europe. Elsevier, Amsterdam, pp. 209-214.

Church, M., Ryder, J.M., 1972. Paraglacial sedimentation: a consideration of fluvial processes conditioned by glaciation. Geol. Soc. Am. Bull. 83, 3059-3072.

Colhoun, E.A., Kiernan, K., Barrows, T.T., Goede, A., 2010. Advances in quaternary studies in Tasmania. In: Bishop, P., Pillans, B. (Eds.), Australian Landscapes, Geological Society of London, Special Publication, vol. 346, pp. 165-183.

Conchon, O., 1978. Quaternary studies in Corsica (France). Quat. Res. 9 (1), 41-53.

Cvijić, J., 1898. Das Rilagebirge und seine ehemalige Vergletscherung. Z. Ges. Erdkd. Berl. 33, 200-253.

Cvijić, J., 1900. L’Époque Glaciaire dans la Péninsule des Balkans. Ann. Géogr. 9, $359-372$.

Ducić, V., Luković, J., Burić, D., Stanojevic, G., Mustafić, S., 2012. Precipitation extremes in the wettest Mediterranean region (Krivošije) and associated atmospheric circulation types. Nat. Hazards Earth Syst. Sci. 12, 687-697.

Dühnforth, M., Densmore, A.L., Ivy-Ochs, S., Allen, P.A., 2008. Controls on sediment evacuation from glacially modified and unmodified catchments in the eastern Sierra Nevada, California. Earth Surf. Process. Landforms 33 (10), 1602-1613.

Edwards, R.L., Chen, H., Wasserburg, G.J., 1987. ${ }^{238} \mathrm{U}-{ }^{234} \mathrm{U}-{ }^{230} \mathrm{Th}-{ }^{232}$ Th systematics and the precise measurement of time over the past 500,000 years. Earth Planet. Sci. Lett. 81, 175-192.

Fontana, A., Mozzi, P., Bondesan, A., 2008. Alluvial megafans in the VenetianFriulian Plain (north-eastern Italy): evidence of sedimentary and erosive phases during the Late Pleistocene and Holocene. Quat. Int. 189, 71-90.

Ford, D., Williams, P., 1989. Karst Geomorphology and Hydrology. Unwin Hyman, London.

Ford, D.C., Williams, P., 2007. Karst Hydrogeology and Geomorphology. Wiley, Oxford.

Fraser, G.S., Cobb, J.C., 1982. Late Wisconsinan proglacial sedimentation long the West Chicago Moraine in northeastern Illinois. J. Sediment. Petrol. 52 (2), 473491.

Fuller, I.C., Macklin, M.G., Lewin, J., Passmore, D.G., Wintle, A.G., 1998. River response to high-frequency climate oscillations in southern Europe over the Past 200 k.y. Geology 26 (3), 275-278.

Gams, I., 1969. Some morphological characteristics of the Dinaric Karst. Geogr. J. 135 (4), 563-572.

Gams, I., 1978. The polje: the problem of its definition. Z. Geomorphol. 22, 170-181.

Gams, I., 2005. Tectonics impact on poljes and minor basins (case studies of Dinaric karst). Acta Carsol. 34 (1), 25-41.

Groupe Spéléologique Muséum National d'Histoire Naturelle, Paris, 2003. Rapport de l'expédition le chemins d'Orjen 2003 organisée par Groupe Spéléologique Minos, Paris. Expédition du 30 juillet au 20 août 2003 au Monténégro (Crna Gora), p. 68.

Hamlin, R.H.B., Woodward, J.C., Black, S., Macklin, M.G., 2000. Sediment fingerprinting as a tool for interpreting long-term river activity: the Voidomatis basin, NW Greece. In: Foster, I.D.L. (Ed.), Tracers in Geomorphology. Wiley, Chichester, pp. 473-501.

Harden, J.W., 1982. A quantitative index of soil development from field descriptions: examples from a chronosequence in central California. Geoderma 28, 1-28.

Harvey, A.M., 2002. Effective timescales of coupling within fluvial systems. Geomorphology 44, 175-201.

Hoffmann, G., 1988. Holozänstratigraphie und Küstenlinienverlagerung an der andalusischen Mittelmeerküste. Berichte aus dem Fachbereich Geowissenschaften der Universität Bremen, Bremen, p. 173.

Hughes, P.D., Woodward, J.C., 2009. Glacial and periglacial environments. In: Woodward, J.C. (Ed.), The Physical Geography of the Mediterranean. Oxford University Press, Oxford, p. 700.

Hughes, P.D., Gibbard, P.L., Woodward, J.C., 2005. Quaternary glacial records in mountain regions: a formal stratigraphical approach. Episodes 28, 85-92.

Hughes, P.D., Woodward, J.C., Gibbard, P.L., Macklin, M.G., Gilmour, M.A., Smith, G.R., 2006a. The glacial history of the Pindus Mountains, Greece. J. Geology 114, 413434.
Hughes, P.D., Woodward, J.C., Gibbard, P.L., 2006b. The last glaciers of Greece. Z. Geomorphol. 50, 37-61.

Hughes, P.D., Woodward, J.C., van Calsteren, P.C., Thomas, L.E., Adamson, K.R., 2010 Pleistocene ice caps on the coastal mountains of the Adriatic Sea. Quat. Sci. Rev. 29 (27-28), 3690-3708.

Hughes, P.D., Woodward, J.C., van Calsteren, P.C., Thomas, L.E., 2011. The glacial history of the Dinaric Alps, Montenegro. Quat. Sci. Rev. 30 (23-24), 3393-3412. Jennings, J.N., 1985. Karst Geomorphology. Blackwell, Oxford.

Kiernan, K., Lauritzen, S.-E., Duhig, N., 2001. Glaciation and cave sediment aggradation around the margins of the Mt Field Plateau, Tasmania. Aust. J. Earth Sci. $48,251-263$

Lewin, J., Woodward, J.C., 2009. Karst geomorphology and environmental change. In: Woodward, J.C. (Ed.), The Physical Geography of the Mediterranean. Oxford University Press, Oxford, p. 700.

Lewis, C.J., McDonald, E.V., Sancho, C., Peña, J.L., Rhodes, E.J., 2009. Climatic implications of correlated Upper Pleistocene glacial and fluvial deposits on the Cinca and Gállego Rivers (NE Spain) based on OSL dating and soil stratigraphy. Global Planet. Change 67, 141-152.

Magaš, D., 2002. Natural-geographic characteristics of the Boka Kotorska area as the basis of development. Geoadria 7/1, 51-81.

Mocochain, L., Clauzon, G., Bigot, J.-V., Brunet, P., 2006. Geodynamic evolution of the peri-Mediterranean karst during the Messinian and the Pliocene: evidence from the Ardèche and Rhône Valley systems canyons, Southern France. Sediment. Geol. 188-189, 219-233.

Macklin, M.G., Woodward, J.C., 2009. Karst geomorphology and environmenta change. In: Woodward, J.C. (Ed.), The Physical Geography of the Mediterranean. Oxford University Press, Oxford, pp. 287-318.

Macklin, M.G., Fuller, I.C., Lewin, J., Mass, G.S., Passmore, D.G., Rose, J., Woodward, J.C., Black, S., Hamlin, R.H.B., Rowan, J.S., 2002. Correlation of fluvial sequences in the Mediterranean basin over the last $200 \mathrm{ka}$ and their relationship to climate change. Quat. Sci. Rev. 21, 1633-1641.

Maddy, D., Demir, T., Veldkamp, A., Bridgland, D.R., Stemerdink, C., van der Schriek, T., Schreve, D., 2012. The obliquity-controlled early Pleistocene terrace sequence of the Gediz River, western Turkey: a revised correlation and chronology. J. Geol. Soc. 169, 67-82.

Mangerud, J., Andersen, S. Th, Berglund, B.E., Donner, J.J., 1974. Quaternary stratigraphy of Norden, a proposal for terminology and classification. Boreas 3, $109-128$

Nicod, J., 2003. A little contribution to the karst terminology: special of aberrant cases of poljes? Acta Carsol. 32(2) (3), 29-39.

Peña, J.L., Sancho, C., Lewis, C., McDonald, E., Rhodes, E., 2004a. Datos cronológicos de las morrenas terminales del glaciar del Gállego y su relación con las terrazas fluvioglaciares (Pirineo de Huesca). In: Peña, J.L., Longares, L.A., Sánchez, M (Eds.), Geografía Física de Aragón. Aspectos generales y temáticos. Universidad de Zaragoza-Instituto Fernando el Católico, pp. 71-84.

Peña, J.L., Lewis, C., McDonald, E., Rhodes, E., Sancho, C., 2004b. Ensayo cronológico del Pleistoceno Medio-Superior en la Cuenca del río Cinca (Pirineos y depresión del Ebro). In: Benito, G. Díez Herrero, A. (Eds.), Contribuciones recientes sobre Geomorfología. Sociedad Española de Geomorfología-Consejo Superior de Investigaciones Científicas, Madrid, pp. 265-270.

Rother, H., Schulmeister, J., Rieser, U., 2010. Stratigraphy, optical dating chronology (IRSL) and depositional model of pre-LGM glacial deposits in the Hope Valley, New Zealand. Quat. Sci. Rev. 29, 576-592.

Rowan, J.S., Black, S., Macklin, M.G., Tabner, B.J., Dore, J., 2000. Quaternary environmental change in Cyrenaica evidenced by U-Th, ESR and OSL of coastal alluvial fan sequences. Libyan Stud. 31, 5-16.

Schulte, L., Julià, R., Burjachs, F., Hilgers, A., 2008. Middle Pleistocene to Holocene geochronology of the River Aguas terrace sequence (Iberian Peninsula): fluvial response to Mediterranean environmental change. Geomorphology $98,13-33$.

Schumm, S.A., 1977. The Fluvial System. John Wiley, New York, p. 338.

Smith, G.W., Nance, D., Genes, A.N., 1997. Quaternary glacial history of mount Olympus, Greece. Geol. Soc. Am. Bull. 109, 809-824.

Stepišnik, U., Žebre, M., 2011. Glaciokras Lovčena E-GeograFF 2. Available at:. Univerza v Ljubljani, Filozofska fakulteta (accessed 10.09.13). http://geo.ff.uni-lj.si/ sites/default/files/glaciokras_lovcena_0.pdf.

Stepišnik, U., Ferk, M., Kodelja, B., Medenjak, G., Mihevc, A., Natek, K., Žebre, M., 2009. Glaciokarst of western Orjen. Cave Karst Sci. 36, 21-28.

Telbisz, T., 2010a. Morphology and GIS-analysis of closed depressions in Sinjajevina Mts (Montenegro). Karst Dev. Orig. Pap. 1 (1), 41-47.

Telbisz, T., 2010b. Glacio-karst features of the Sinjajevina Mts (Montenegro): an overview and DEM-analysis. Karst Dev. 1, 17-22.

Tisserant, J., 1974. Troisième campagne à l'Orjen (Yougoslavie - Monténégro 1976) Bull. Du. Spéléo Club Des. Ardennes 5, 1-25.

Wenzens, G., 1992. The influence of tectonics and climate on the Villafranchian morphogenesis in semiarid Southeastern Spain. Z. Geomorphol. N.F. Suppl. 84, $173-184$.

Woodward, J.C., Hughes, P.D., 2011. Glaciation in Greece: a new record of cold stage environments in the Mediterranean. In: Ehlers, J., Gibbard, P.L., Hughes, P.D. (Eds.), Quaternary Glaciations - Extent and Chronology - a Closer Look Elsevier, Amsterdam, pp. 175-198.

Woodward, J.C., Lewin, J., Macklin, M.G., 1992a. Alluvial sediment sources in a glaciated catchment: the Voidomatis basin, northwest Greece. Earth Surf. Process. Landforms 17, 205-216. 
Woodward, J.C., Lewin, J., Macklin, M.G., 1992b. Alluvial sediment sources in a glaciated catchment: the Voidomatis basin, northwest Greece. Earth Surf. Process. Landforms 17, 205-216.

Woodward, J.C., Lewin, J., Macklin, M.G., 1995. Glaciation, river behaviour and the Palaeolithic settlement of upland northwest Greece. In: Lewin, J., Macklin, M.G., Woodward, J.C. (Eds.), Mediterranean Quaternary River Environments. Balkema, Rotterdam, pp. 115-129.

Woodward, J.C., Macklin, M.G., Lewin, J., 1994. Pedogenic weathering and relative age dating of Quaternary alluvial sediments in the Pindus Mountains of northwest Greece. In: Robinson, D.A., Williams, R.B.G. (Eds.), Rock Weathering and Landform Evolution. John Wiley \& Sons, pp. 259-283.

Woodward, J.C., Macklin, M.G., Smith, G.R., 2004. Pleistocene glaciation in the mountains of Greece. In: Ehlers, J., Gibbard, P.L. (Eds.), Quaternary Glaciations Extent and Chronology Part 1: Europe. Elsevier, Amsterdam, p. 475.

Woodward, J.C., Hamlin, R.H.B., Macklin, M.G., Hughes, P.D, Lewin, J., 2008. Glacial activity and catchment dynamics in northwest Greece: long-term river behaviour and the slackwater sediment record for the last glacial to interglacial transition. Geomorphology 101, 44-67. 